\title{
Review and parameterisation of bi-directional ammonia exchange between vegetation and the atmosphere
}

\author{
R.-S. Massad ${ }^{1}{ }^{*}$, E. Nemitz ${ }^{1}$, and M. A. Sutton ${ }^{1}$ \\ ${ }^{1}$ Center for Ecology and Hydrology, Edinburgh Research Station, Bush Estate, Penicuik Midlothian EH26 0QB, UK \\ *now at: INRA, AgroParisTech, UMR 1091 EGC, 78850 Thiverval Grignon, France
}

Received: 29 March 2010 - Published in Atmos. Chem. Phys. Discuss.: 20 April 2010

Revised: 25 October 2010 - Accepted: 26 October 2010 - Published: 4 November 2010

\begin{abstract}
Current deposition schemes used in atmospheric chemical transport models do not generally account for bidirectional exchange of ammonia $\left(\mathrm{NH}_{3}\right)$. Bi-directional exchange schemes, which have so far been applied at the plot scale, can be included in transport models, but need to be parameterised with appropriate values of the ground layer compensation point $\left(\chi_{\mathrm{g}}\right)$, stomatal compensation point $\left(\chi_{\mathrm{s}}\right)$ and cuticular resistance $\left(R_{\mathrm{w}}\right)$. We review existing measurements of $\chi_{g}, \chi_{\mathrm{s}}$ as well as $R_{\mathrm{W}}$ and compile a comprehensive dataset from which we then propose generalised parameterisations. $\chi_{\mathrm{s}}$ is related to $\Gamma_{\mathrm{s}}$, the non-dimensional ratio of $\left[\mathrm{NH}_{4}^{+}\right]_{\text {apo }}$ and $\left[\mathrm{H}^{+}\right]_{\text {apo }}$ in the apoplast, through the temperature dependence of the combined Henry and dissociation equilibrium. The meta-analysis suggests that the nitrogen $(\mathrm{N})$ input is the main driver of the apoplastic and bulk leaf concentrations of ammonium $\left(\mathrm{NH}_{4}^{+}\right.$apo, $\left.\mathrm{NH}_{4 \text { bulk }}^{+}\right)$. For managed ecosystems, the main source of $\mathrm{N}$ is fertilisation which is reflected in a peak value of $\chi_{\mathrm{s}}$ a few days following application, but also alters seasonal values of $\mathrm{NH}_{4}^{+}$apo and $\mathrm{NH}_{4}^{+}$bulk. We propose a parameterisation for $\chi_{s}$ which includes peak values as a function of amount and type of fertiliser application which gradually decreases to a background value. The background $\chi_{\mathrm{s}}$ is based on total $\mathrm{N}$ input to the ecosystem as a yearly fertiliser application and $\mathrm{N}$ deposition $\left(N_{\mathrm{dep}}\right)$. For non-managed ecosystems, $\chi_{\mathrm{s}}$ is parameterised based solely on the link with $N_{\text {dep }}$.
\end{abstract}

For $R_{\mathrm{W}}$ we propose a general parameterisation as a function of atmospheric relative humidity $(\mathrm{RH})$, incorporating a minimum value $\left(R_{\mathrm{w}(\min )}\right)$, which depends on the ratio of atmospheric acid concentrations $\left(\mathrm{SO}_{2}, \mathrm{HNO}_{3}\right.$ and $\left.\mathrm{HCl}\right)$ to

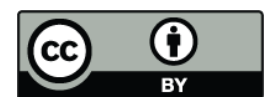

Correspondence to: R.-S. Massad (massad@grignon.inra.fr)
$\mathrm{NH}_{3}$ concentrations. The parameterisations are based mainly on datasets from temperate locations in northern Europe making them most suitable for up-scaling in these regions (EMEP model for example). In principle, the parameterisations should be applicable to other climates, though there is a need for more underpinning data, with the uncertainties being especially large for tropical and subtropical conditions.

\section{Introduction}

Ammonia $\left(\mathrm{NH}_{3}\right)$ is a major atmospheric acid-neutralising agent that plays an important role in aerosol formation (Finlayson-Pitts and Pitts, 1999). Aerosols impact on human health, decrease visibility, and affect atmospheric radiative forcing (Adams et al., 2001; Ramanathan et al., 2007). Once deposited, $\mathrm{NH}_{3}$ contributes to soil acidification and species and habitat loss due to excess nutrient loading (Sutton et al., 1993c; Krupa, 2003; Sutton et al., 2009c). Biological processes in soils enriched by reduced nitrogen $\left(\mathrm{NH}_{\mathrm{x}}\right)$ can lead to emissions of $\mathrm{NH}_{3}, \mathrm{NO}_{\mathrm{x}}$ and also of nitrous oxide $\left(\mathrm{N}_{2} \mathrm{O}\right)$, a greenhouse gas (Mosier et al., 1998). The use of $\mathrm{NH}_{\mathrm{x}}$ as a fertiliser in agriculture has dramatically increased over the past century and the trend is expected to continue with an increasing demand for biofuels and to simply meet the nutritional requirements of an increasing global population (Galloway et al., 2003; Erisman et al., 2008). The impacts of human activity on the nitrogen cycle have prompted active research into the parameterisation of $\mathrm{NH}_{3}$ emissions and deposition in air quality models for determining sound regulatory scenarios for human exposure to particulates, ecosystem nutritive loading and climate change (Sutton et al., 2008).

Published by Copernicus Publications on behalf of the European Geosciences Union. 
Direct flux measurements over the past 20 years have shown that vegetation can be a source or a sink of atmospheric $\mathrm{NH}_{3}$ (e.g., Farquhar et al., 1980; Sutton et al., 1995b). The direction and magnitude of the exchange depends on the concentration gradient between the canopy and the atmosphere. The canopy compensation point $\left(\chi_{c}\right)$ is the atmospheric $\mathrm{NH}_{3}$ concentration for which the flux between the surface and the atmosphere switches from emission to deposition (or vice versa) (Farquhar et al., 1980). $\chi_{\mathrm{c}}$ is the net effect of different exchange pathways with the ecosystem and includes contributions from the plant (stomata and cuticle), leaf litter and soil (Sutton et al., 1995b). The cuticles are mainly a sink for $\mathrm{NH}_{3}$ (van Hove et al., 1989). As ammonia is soluble, it can deposit rapidly to leaf cuticles (Sutton et al., 1993a; Duyzer, 1994), though cuticular uptake tends to saturate at high atmospheric $\mathrm{NH}_{3}$ concentrations (Jones et al., 2007b), and can be enhanced in the presence of atmospheric acids (van Hove et al., 1989; Erisman and Wyers, 1993; Nemitz et al., 2001). The consequence is that the resistance for $\mathrm{NH}_{3}$ deposition to plant surfaces are controlled by many factors including the availability of moisture, leaf area and atmospheric chemistry. It should be noted that cuticular emissions can also occur as a consequence of desorption when leaf water layers dry out (Flechard et al., 1999). This tends to be a transient process which cannot be sustained over long periods. By contrast, the stomatal flux is typically bi-directional, depending on the concentration gradient of $\mathrm{NH}_{3}$ between the sub-stomatal cavity (stomatal compensation point: $\chi_{\mathrm{s}}$ ) and the canopy air. $\chi_{\mathrm{s}}$ is the $\mathrm{NH}_{3}$ air concentration in the leaf sub-stomatal cavity that is in equilibrium with ammonium $\left(\left[\mathrm{NH}_{4}^{+}\right]_{\text {apo }}\right)$ concentrations in the apoplast (Farquhar et al., 1980; Schjoerring et al., 1998a). It can be calculated from the ratio of apoplastic $\left[\mathrm{NH}_{4}^{+}\right]_{\text {apo }}$ to $\left[\mathrm{H}^{+}\right]_{\text {apo }}$ concentrations (the emission potential $\Gamma_{\mathrm{s}}$ ), corrected by a thermodynamic temperature function (Nemitz et al., 2001). $\Gamma_{\mathrm{s}}$ depends on the plant nitrogen $(\mathrm{N})$ metabolism as well as influxes and outfluxes of various $\mathrm{N}$ forms to the leaf (Massad et al., 2008). Its value therefore depends strongly on landuse and management as well as growth stage throughout the season (Riedo et al., 2002).

Despite the recognition of these dynamics with leaf tissues and surfaces, current deposition schemes used in regional and global models tend to be rather simplified and out of date. For example, in many models such as CHIMERE (Vautard et al., 2001) or CMAQ (Byun and Schere, 2006), dry deposition of $\mathrm{NH}_{3}$ is calculated according to the parameterisation scheme of Wesley (1989) or related approaches. This is based on look-up tables of the deposition velocity $\left(V_{\mathrm{d}}=\right.$ flux/atmospheric concentration) and canopy resistance components $\left(R_{\mathrm{c}}\right)$ for different ecosystems and climatic/seasonal conditions. It does not account for bi-directional exchange and there is no dependence of cuticular $\mathrm{NH}_{3}$ uptake on leaf wetness (except for fully wet canopies).

The testing of bi-directional exchange schemes in transport models is rather limited (Sorteberg and Hov, 1996;
Vieno, 2006). Recent improvements in the understanding of the underlying processes involved in vegetation-atmosphere $\mathrm{NH}_{3}$ exchange thus need to be included in regional and global models. Efforts are being made to derive a generalised parameterisation for bi-directional exchange of $\mathrm{NH}_{3}$ to be included in chemistry and transport models: Zhang et al. (2010) in AURAMS (A Unified Regional Air-quality Modelling System, developed by Environment Canada) and Cooter and Bash (2009) in CMAQ (Community Multiscale Air-Quality Modeling System, developed by the US Environmental Protection Agency). This is essential as a basis for surface-atmosphere exchange modules to respond to changes in climate, chemical composition and vegetation status, as well as to evaluate the success of air pollution mitigation strategies (Sutton et al., 2003; Bleeker et al., 2009). The Unified EMEP model (Simpson et al., 2003, 2006) is the reference atmospheric dispersion model used in supporting the development of air quality policies under the EU Commission. Along with other large-scale models, the EMEP model generally under-estimates $\mathrm{NH}_{3}$ concentrations, especially close to source areas (e.g., van Pul et al., 2009). This is likely due to an inability to resolve large vertical gradients of $\mathrm{NH}_{3}$ near source areas, as well as the lack of a bi-directional approach as discussed in this study. It should be noted that over forested areas the EMEP model has been found to overestimate $\mathrm{NH}_{3}$ concentrations in one study (Simpson et al., 2006).

In this paper, we first review recent progress in elucidating the mechanisms driving the air-surface exchange of ammonia at the plot scale, as represented in existing bi-directional exchange modelling approaches. Here, the key parameterisations, specific to $\mathrm{NH}_{3}$, needed by these models are those of $\Gamma_{\mathrm{s}}$ and $\chi_{\mathrm{s}}$, as well as the resistance to $\mathrm{NH}_{3}$ deposition to the leaf cuticle $\left(R_{\mathrm{W}}\right)$. We then compile data from existing measurements, highlighting current understanding of the physical, chemical and biological processes that control surface/atmosphere exchange. Finally, based on the measurements reviewed, we propose a new operational parameterisation for integrating bi-directional $\mathrm{NH}_{3}$ exchange into chemical transport models and earth system models.

\section{Review of existing modelling approaches}

Field-scale $\mathrm{NH}_{3}$ exchange models that account for bidirectional stomatal exchange and cuticular deposition were developed and adapted in a number of applications (e.g., Sutton and Fowler, 1993; Sutton et al., 1995b; Sutton et al., 1998b; Nemitz et al., 2001). In the single-layer (or 'bigleaf') version of these models (Fig. 1a), plant-atmosphere exchange of $\mathrm{NH}_{3}$ is governed by two main parallel pathways: deposition to leaf surfaces and bi-directional exchange with the leaf apoplast through the stomata. A two-layer model can be developed by adding $\mathrm{NH}_{3}$ exchange with the soil surface (Fig. 1b) (Nemitz et al., 2001). A multi-layer model 
including soil emissions together with different layers in the plant canopy (inflorescences, bottom senescing leaves, etc.) has also been developed (Nemitz et al., 2000b). While this may be useful for assessing cycling processes in specific canopies at the plot scale, the multi-layer model requires a very large number of parameters and therefore represents a higher degree of complexity than is merited for integration into large scale models considering several ecosystem types.

Exchange of $\mathrm{NH}_{3}$ with the soil is most important after fertilisation, but may also be important for barren land and in highly senescent plant canopies where leaf litter on the soil surface contributes to emissions (e.g. Nemitz et al., 2000a; Sutton et al., 2009a). Currently, ammonia emissions from leaf litter, though understood in principle, remain very uncertain due to the limited number of studies (Sarwar et al., 2005; David et al., 2009). For short semi-natural vegetation and agricultural vegetation during the growth stage, any soil emissions are expected to be largely recaptured by the overlying canopy (cf. Nemitz et al., 2000a). This is different in drier desert climates or for recently cut vegetation (Personne et al., 2009; Sutton et al., 2009a). In this work we focus on reviewing and deriving generalised parameterisations for the two-layer model, although, it is not always possible to include the soil/litter surface layer which requires further assessment before it can be incorporated into the model in all situations. Coupling a suitable litter decomposition module to canopy level ammonia exchange represents a future priority (Sutton et al., 2009a).

In order for a two layer model to be applied at large scales, generalised parameterisation of the resistances $\left(R_{\mathrm{a}}, R_{\mathrm{b}}, R_{\mathrm{ac}}\right.$, $R_{\mathrm{bg}}, R_{\mathrm{S}}$ and $\left.R_{\mathrm{W}}\right)$ as well as the stomatal $\left(\chi_{\mathrm{s}}\right)$ and the ground layer $\left(\chi_{\mathrm{g}}\right)$ compensation points are required. The two-layer model simplifies into the single-layer model if the in-canopy resistance $\left(R_{\mathrm{g}}\right)$ is set to infinity. Detailed parameterisations of atmospheric and in-canopy resistances are given in Sects. 4.2 and 4.3.

\subsection{Stomatal resistance $\left(R_{\mathrm{S}}\right)$}

The stomatal resistance also governs the exchange of water, $\mathrm{CO}_{2}$ and $\mathrm{O}_{3}$ and has been well researched and tabulated (e.g., Jarvis, 1976; Wang and Leuning, 1998; Dewar, 2002). If values derived for other gases are applied for $\mathrm{NH}_{3}$, they need to be adjusted for differences in the molecular diffusivity:

$$
R_{\mathrm{SNH}_{3}}=R_{\mathrm{Sx}} \times \frac{D_{\mathrm{x}}}{D_{\mathrm{NH}_{3}}}
$$

where $R_{\mathrm{sx}}$ and $D_{\mathrm{x}}$ are the stomatal resistance and diffusivity in air of the derived gas, respectively. $D_{\mathrm{NH}_{3}}$ varies with temperature and can be determined from the equation proposed by Massman (1998) at $1 \mathrm{~atm}$ atmospheric pressure where $T$ is the temperature in ${ }^{\circ} \mathrm{K}$ :

$D_{\mathrm{NH}_{3}}(T)=0.1987 \times\left(\frac{T}{273.13}\right)^{1.81}$ (a)

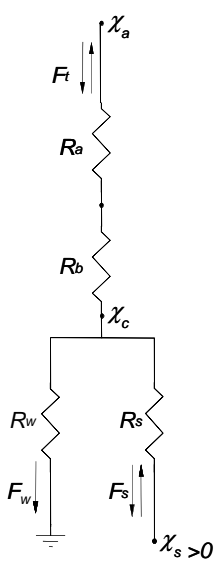

(b)

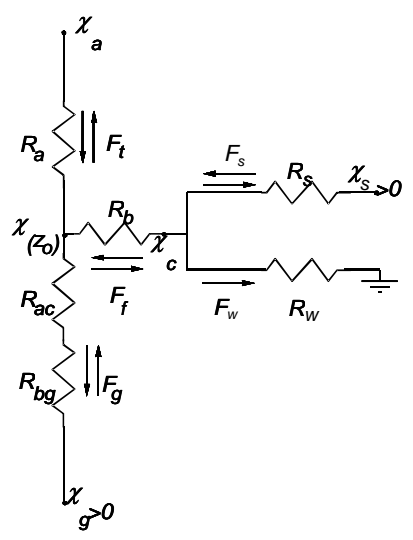

Fig. 1. Big leaf (a) and two layer (b) resistance scheme for bidirectional $\mathrm{NH}_{3}$ exchange between the vegetation and the atmosphere from Sutton et al. (1995b). $F_{\mathrm{t}}, F_{\mathrm{S}}, F_{\mathrm{W}}$ and $F_{\mathrm{g}}$ are the total, stomatal, cuticular and ground layer fluxes of $\mathrm{NH}_{3}$ respectively; $R_{\mathrm{a}}$, $R_{\mathrm{b}}, R_{\mathrm{W}}, R_{\mathrm{S}}, R_{\mathrm{ac}}$ and $R_{\mathrm{bg}}$ are the aerodynamic, leaf boundary layer, cuticular, stomatal, in canopy aerodynamic and ground boundary layer resistances to exchange; $\chi_{\mathrm{a}}$ is the atmospheric $\mathrm{NH}_{3}$ concentration; $\chi_{\mathrm{c}}, \chi_{\mathrm{s}}$ and $\chi_{\mathrm{g}}$ are the canopy, stomatal and ground layer $\mathrm{NH}_{3}$ compensation points respectively.

\subsection{Cuticular resistance $\left(R_{\mathrm{w}}\right)$}

The cuticular resistance is one of the key parameters in modelling bi-directional $\mathrm{NH}_{3}$ exchange and cannot be derived from parameterisations for other chemical species. It is mainly influenced by the wetness of the surface and its pH (van Hove et al., 1989; Sutton et al., 1995a; Wyers and Erisman, 1998). A simple dynamic model of ammonia adsorption and desorption with the cuticular water pool was developed by Sutton et al. (1998a), which was dependent on specifying set leaf surface $\mathrm{pH}$, as may be established from dew chemistry measurements. Flechard et al. (1999) extended this concept to develop a more detailed mechanistic approach that accounts for inorganic chemistry interactions on the leaf surface, using a chemical model to simulate the temporal $\mathrm{pH}$ dynamics in response to the air concentration and simultaneous exchange of several trace gases, aerosols and wet deposition. Although such dynamic models can successfully simulate $\mathrm{NH}_{3}$ fluxes at the plot scale (e.g. Neirynck and Ceulemans, 2008; Burkhardt et al., 2009), they require excessive computing time to be integrated in large scale models, such as chemical transport or deposition models (e.g., requiring many iterations, short time-steps and a large number of input parameters). Simpler empirical approaches are therefore needed, such as that investigated by Wichink-Kruit et al. (2010) who examined the potential for a non-zero cuticular concentration to depend on atmospheric ammonia concentrations. 
Exchange of ammonia between plant cuticles and the atmosphere depends on the amount of atmospheric acids present and, in particular, on the thickness and chemical composition of the leaf-surface water-layer. A frequent simplification in models is to assume that the ammonia concentration at the leaf surface is zero, thereby defining a resistance for cuticular deposition $\left(R_{\mathrm{W}}\right)$, for transfer between the canopy air space (represented by $\chi_{\mathrm{c}}$ ) and the leaf surface (Sutton and Fowler, 1993; Sutton et al., 1995a; Nemitz et al., 2001 ). Although there is no way to measure $R_{\mathrm{w}}$ directly, it can be derived from night-time measurements. In this approach, it is assumed that stomata are effectively closed at night so that stomatal exchange is negligible (van Hove et al., 1989), and $R_{\mathrm{W}}$ can be approximated by the bulk canopy resistance $\left(R_{\mathrm{c}}\right)$ (Sutton et al., 1995b; Wyers and Erisman, 1998; Spindler et al., 2001).

$R_{\mathrm{w}}$ estimated during night-time by this approach is reported to have a clear relationship to surface relative humidity $(\mathrm{RH})$, because invisible water films form on leaf cuticles, stems and other non-stomatal surfaces in the canopy, and their thickness is controlled by RH (van Hove and Adema, 1996). These water layers provide efficient sinks for atmospheric $\mathrm{NH}_{3}$ (Sutton et al., 1995b; Flechard et al., 1999). Other factors that have been reported to affect $R_{\mathrm{w}}$ include the following:

- Interactions with acid gases. Rates of ammonia dry deposition to leaf surfaces can be enhanced or suppressed by the presence of acid or basic agents, respectively. Thus, while the deposition of ammonia leads to alkalinisation of the leaf surface, simultaneous deposition of $\mathrm{SO}_{2}$ would neutralise the deposited $\mathrm{NH}_{3}$. The specific interaction between ammonia and $\mathrm{SO}_{2}$ is well known and has been termed "co-deposition", the idea being that the presence of both $\mathrm{NH}_{3}$ and $\mathrm{SO}_{2}$ would tend to decrease $R_{\mathrm{w}}$ and increase the deposition rate for both gases (van Hove et al., 1987; Erisman and Wyers, 1993; Sutton et al., 1994, Fowler et al., 2009). Co-deposition of $\mathrm{SO}_{2}$ and $\mathrm{NH}_{3}$ was suspected in some field experiments (Flechard and Fowler, 1998; Wyers and Erisman, 1998). Firm field evidence has always proven difficult to obtain because of the interaction of several factors influencing $\mathrm{NH}_{3}$ fluxes ( $\mathrm{RH}$, stomatal flux, etc.), even with the observation that $\mathrm{SO}_{2}$ rich acidic plumes can deplete $\mathrm{NH}_{3}$ concentration promoting $\mathrm{NH}_{3}$ emissions (Sutton et al., 1994). However, the synergistic effect of $\mathrm{SO}_{2}$ and $\mathrm{NH}_{3}$ in promoting deposition has been successfully modelled (Flechard et al., 1999; Burkhardt et al., 2009) and implied through the comparison of field observations (Nemitz et al., 2001). The co-deposition effect of $\mathrm{SO}_{2}$ on $\mathrm{NH}_{3}$ deposition has been implemented in the EMEP model as the reciprocal of the effect of $\mathrm{NH}_{3}$ co-deposition on $\mathrm{SO}_{2}$ deposition, which can be seen in field measurements (H. Fagerli et al., personal communication, 2010; Fowler et al., 2009). It should be noted that leaf surface chemistry can also be influenced by the deposition of other atmospheric acids such as $\mathrm{HCl}$ or $\mathrm{HNO}_{3}$, which, following the decline of $\mathrm{SO}_{2}$ emissions make an increasingly large relative contribution to the acid loading, at least in Europe and North America.

- Very high concentrations of ammonia. It has been known for a long time that very high concentrations of ammonia tend to saturate leaf cuticular water pools, potentially reducing deposition velocities, because under these conditions the neutralising effect of the acids becomes negligible (Sommer and Jensen, 1991; Sutton et al., 1993c). However, until recently there were few data specifically generated to quantify the dependence of $R_{\mathrm{W}}$ on atmospheric ammonia concentrations. Jones et al. $(2007 \mathrm{a}, \mathrm{b})$ studied this phenomenon over a wide concentration range and reported an increase in $R_{\mathrm{w}}$ with increasing $\mathrm{NH}_{3}$ concentration in the atmosphere for a range of heathland species.

- Temperature. Temperature is one of the major controllers of $\mathrm{NH}_{3}$ gaseous exchange. Temperature affects $\mathrm{NH}_{3}$ thermodynamics via the $\mathrm{NH}_{3} / \mathrm{NH}_{4}^{+}$dissociation equilibria and the Henry constant (Farquhar et al., 1980; Nemitz et al., 2001). Temperature also plays a role via its effect on RH especially through the relationship of $R_{\mathrm{w}}$ on RH. A more explicit way of seeing this effect is by looking at $R_{\mathrm{W}}$ as a function of vapour pressure deficit (VPD) instead of RH (e.g., Nemitz et al., 2004). Recently, Flechard et al. (2010) derived a parameterisation of $R_{\mathrm{w}}$ as a function of both RH and temperature for measurements made over a grassland in Switzerland, with an exponential increase of $R_{\mathrm{w}}$ with surface temperature for non-freezing conditions.

- Leaf surface area and properties. The effective leaf surface area on which $\mathrm{NH}_{3}$ can be deposited influences $R_{\mathrm{w}}$. The leaf area index (LAI) was accounted for in parameterisation of $R_{\mathrm{w}}$ by Zhang et al. (2003). Different leaf surface characteristics also affect $R_{\mathrm{w}}$ and might be the explanation for differences between different plant species. Rudich et al. (2000) discuss the dependence of the formation, growth and fate of water films on organic surfaces on the chemical composition and corrugation degree of the surface. For example, Klemm et al. (2002) and Wichink-Kruit et al. (2008) show that water stays longer on grass leaves compared with forest leaves. Furthermore, water film development on leaf surfaces is influenced by salts and solutes originating from atmospheric deposition of aerosols and other gases, as well as by cuticular leaching and the deposition of calcareous soil particles (Sutton et al., 1993c; Burkhardt et al., 2009). 
Table 1. Compiled data of $R_{\mathrm{W}}$ as a function of $\mathrm{RH}^{1}$.

\begin{tabular}{|c|c|c|c|c|c|c|c|c|c|c|c|}
\hline & Type & Specifications & $\begin{array}{r}R_{\mathrm{w}(\min )} \\
\mathrm{s} \mathrm{m}^{-1}\end{array}$ & $a$ & conditions & $\begin{array}{r}{\left[\mathrm{NH}_{3}\right]_{\mathrm{atm}}} \\
\mu \mathrm{g} \mathrm{m} \mathrm{m}^{-3}\end{array}$ & $\begin{array}{r}\mathrm{LAI} \\
\text { one sided } \\
\mathrm{m}^{2} \mathrm{~m}^{-2}\end{array}$ & $\begin{array}{r}\text { Average } \\
\text { temperature } \\
{ }^{\circ} \mathrm{C}\end{array}$ & Reference & $\begin{array}{r}\text { Total } \\
\text { acid/ } \mathrm{NH}_{3}{ }^{2} \\
\text { molar ratio }\end{array}$ & Reference \\
\hline 1 & arable & oilseed rape & 0.93 & 0.369 & & 1.03 & 6.5 & 15 & (Nemitz et al., 2001) & 1.79 & (Sutton et al., 2000) \\
\hline 2 & arable & Soybean & 172 & 0 & wet & 5.5 & 6 & 30 & (Walker et al., 2006) & 0.57 & (Walker et al., 2006) \\
\hline 3 & arable & Soybean & 230 & 0 & dry & 5.5 & 6 & 30 & (Walker et al., 2006) & 0.57 & (Walker et al., 2006) \\
\hline 4 & arable & wheat & 5 & 0.143 & & 3.09 & 4 & 10 & (Sutton et al., 1996a) & 0.73 & EMEP model $^{3}$ \\
\hline 5 & arable & wheat & 2 & 0.083 & & 3.5 & 3 & 8 & (Sutton and Fowler, 1993) & 1.96 & (Sutton et al., 1995a) \\
\hline 6 & forest & conifers & 3.2 & 0.050 & $\mathrm{NH}_{3} / \mathrm{SO}_{2}>5$ & 2.3 & 3 & 15 & (Neirynck and Ceulemans, 2008) & 3.48 & (Neirynck et al., 2007) \\
\hline 7 & forest & conifers & 24 & 0.020 & $1<\mathrm{NH}_{3} / \mathrm{SO}_{2}<5$ & 4 & 3 & 15 & (Neirynck and Ceulemans, 2008) & 1.40 & (Neirynck et al., 2007) \\
\hline 8 & forest & conifers & 71 & 0.010 & $\mathrm{NH}_{3} / \mathrm{SO}_{2}<1$ & 4.2 & 3 & 15 & (Neirynck and Ceulemans, 2008) & 0.82 & (Neirynck et al., 2007) \\
\hline 9 & forest & Douglas Fir & 26 & 0.029 & 1994 & 4.5 & 4 & 12 & (Wyers and Erisman, 1998) & 0.99 & (Wyers and Erisman, 1998) \\
\hline 10 & forest & Douglas Fir & 9.1 & 0.050 & 1993 & 5.6 & 4 & 11 & (Wyers and Erisman, 1998) & 0.84 & (Wyers and Erisman, 1998) \\
\hline 11 & grassland & agricultural & 30 & 0.143 & & 5 & 3 & 15 & (Personne et al., 2009) & 0.19 & (Sutton et al., 2009b) \\
\hline 12 & grassland & agricultural & 5 & 0.143 & & 1.9 & 2 & 15 & (Milford et al., 2001b) & 0.55 & (Milford et al., 2001b) \\
\hline 13 & grassland & agricultural & 20 & 0.008 & & 3 & 2 & 10 & (Fowler et al., 2007) & 0.16 & UK monitoring network \\
\hline 14 & grassland & agricultural & 10 & 0.110 & & 3.13 & 2 & 10 & (Flechard et al., 2010) & 0.44 & (Flechard et al., 2010) \\
\hline 15 & grassland & semi-natural & 30 & 0.143 & & 3.23 & 2 & 11 & (Sutton et al., 1997) & 0.38 & (Sutton et al., 1997) \\
\hline 16 & grassland & semi-natural & 1 & 0.074 & summer & 1.45 & 0.75 & 20 & (Horvath et al., 2005) & 0.63 & (Horvath et al., 2005) \\
\hline 17 & grassland & semi-natural & 30 & 0.369 & winter & 1.84 & 2 & 8 & (Horvath et al., 2005) & 0.67 & (Horvath et al., 2005) \\
\hline 18 & grassland & semi-natural & 1 & 0.209 & autumn & 2.62 & 3.5 & 10 & (Horvath et al., 2005) & 0.43 & (Horvath et al., 2005) \\
\hline 19 & grassland & semi-natural & 1 & 0.381 & spring & 3.02 & 4 & 12 & (Horvath et al., 2005) & 0.30 & (Horvath et al., 2005) \\
\hline 20 & semi-natural & dry heathland & 19 & 0.048 & & 5.2 & 2.5 & 15 & (Nemitz et al., 2004) & 0.39 & (Nemitz et al., 2004) \\
\hline 21 & semi-natural & dry heathland & 24 & 0.069 & $\mathrm{RH}<81.3 \%$ & 5.2 & 2.5 & 15 & (Erisman et al., 1994) & 0.71 & EMEP model $^{3}$ \\
\hline 21 & semi-natural & dry heathland & 1 & 0.278 & $\mathrm{RH}>81.3 \%$ & 5.2 & 2.5 & 15 & (Erisman et al., 1994) & 0.71 & EMEP model $^{3}$ \\
\hline 22 & semi-natural & bog heathland & 0.5 & 0.083 & & 0.26 & 2.5 & 11 & (Milford et al., 2001a) & 1.41 & UK monitoring network \\
\hline 23 & semi-natural & bog heathland & 20 & 0.045 & & 0.95 & 2 & 12 & (Flechard et al., 1999) & 1.80 & (Flechard et al., 1999) \\
\hline
\end{tabular}

${ }^{1} R_{\mathrm{W}} \min$ and $a$ are parameters of the following equation for $R_{\mathrm{W}}$ as a function of $\mathrm{RH}: R_{\mathrm{W}}=R_{(\mathrm{w}) \min } \times \exp ^{a(100-\mathrm{RH})}$

2 Total acid/ $/ \mathrm{NH}_{3}$ ratio (AR) is calculated using the following equation where concentrations are in $M$ : total acid/ $/ \mathrm{NH}_{3}(\mathrm{AR})=\left(2\left[\mathrm{SO}_{2}\right]+[\mathrm{HNO}-\overline{3}]+[\mathrm{HCl}]\right) /\left[\mathrm{NH}_{3}\right]$.

${ }^{3}$ EMEP modelled concentrations were obtained from the model run for the year the measurements were conducted in (1990) and for the grid where the measurement site is situated (Simpson et al. 2003, 2006).

The parameterisations found in the literature for $R_{\mathrm{w}}$ are generally an exponential curve function of relative humidity having the following form:

$R_{\mathrm{W}}=R_{\mathrm{W}(\min )} \times e^{a \times(100-\mathrm{RH})}$

where $R_{\mathrm{w}(\mathrm{min})}$ is the minimum cuticular resistance in $\mathrm{s} \mathrm{m}^{-1}$, $\mathrm{RH}$ is the relative humidity in \% and $a$ is an empirical factor (Sutton and Fowler, 1993).

Table 1 summarises 22 different functions of $R_{\mathrm{w}}$ for various ecosystem types proposed in the literature.

$R_{\mathrm{w}(\min )}$ was previously found to decrease with increasing $\mathrm{SO}_{2}$ to $\mathrm{NH}_{3}$ ratio in the atmosphere (Nemitz et al., 2001), whereas $a$ is expected to increase with a decrease in plant surface hygroscpicity and aerosol deposition and thus change with plant species. We therefore choose to subdivide ecosystem types for $R_{\mathrm{w}}$ parameterisation as a function of leaf characteristics. Consistent with the detail of landcover information typically available to atmospheric transport models, we distinguish the four following ecosystem types: forests, arable crops, short semi-natural (mostly heathlands) and grassland (managed and unmanaged).

The major factors reported to affect $R_{\mathrm{w}}$ are temperature, relative humidity and co-deposition with acidic compounds. Sulphur dioxide $\left(\mathrm{SO}_{2}\right)$ was the main acidic gas in the atmosphere in the 1980's. Major efforts for reducing emissions were successful (Fowler et al., 2005) and now it is important to consider $\mathrm{HCl}, \mathrm{HNO}_{3}$ and $\mathrm{SO}_{2}$ together when accounting for acid gases. Flechard et al. (2010) suggest an effect of temperature (average study reported temperature) on $R_{\mathrm{W}}$ while Zhang et al. (2003) suggest an effect of LAI (one-sided $-\mathrm{m}^{2} \mathrm{~m}^{-2}$ ). We combine the two equations of Flechard et al. (2010) and Zhang et al. (2003) into equation 4 below and apply it to correct $R_{\mathrm{w}}$ :

$R_{\mathrm{w}(\text { corr })}=\frac{R_{\mathrm{w}} \times e^{0.15 \times T}}{(\mathrm{LAI})^{0.5}}$

$R_{\mathrm{w}(\mathrm{corr})}$ is the corrected cuticular resistance and $R_{\mathrm{W}}$ the cuticular resistance as reported by the literature in $\mathrm{s} \mathrm{m}^{-1}$. Figure 2 shows the different $R_{\mathrm{w} \text { (corr) }}$ curves as a function of $\mathrm{RH}$ at height $d+z 0$. We note the important scatter in the dataset and no clear relationship either between $R_{\mathrm{W}}$ and RH or $R_{\mathrm{w}}$ and the acid ratio. One of the reasons for this might be the use of water vapour and $\mathrm{NH}_{3}$ concentrations at a height $z 0$ instead of leaf level which could be significantly different. This information however was not available for all the collected dataset and we therefore chose to consider measurements done at $z 0$ for consistency. We also note that $R_{\mathrm{W}}$ curves as a function of $\mathrm{RH}$ are in general flatter for forests than other types of ecosystems particularly for conifers. This might be the result of the needle shape and waxy surface of the leaves that would retain less water at high relative humidity than other types of plants and therefore have a higher $R_{\mathrm{w}}$. This highlights the importance of accounting for leaf surface characteristics while studying $R_{\mathrm{w}}$. 


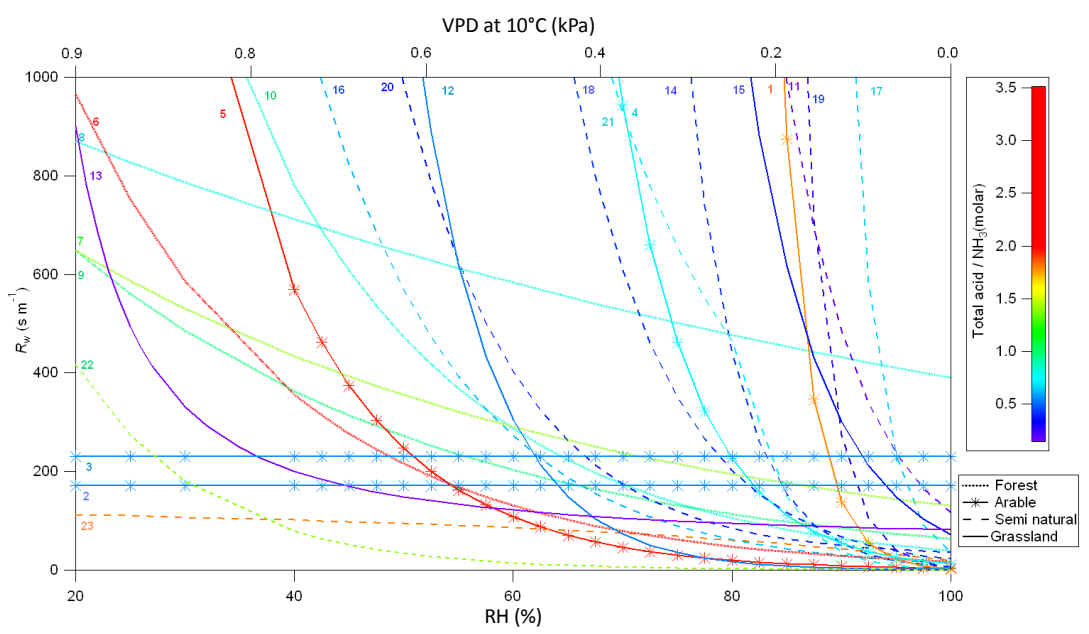

Fig. 2. Compilation of cuticular resistance $\left(R_{\mathrm{w}(\mathrm{corr})}\right)$ as a function of relative humidity $(\mathrm{RH})$ at height $z 0$ separated according to ecosystem type. Dotted lines represent forest ecosystems, short dashed lines represent short semi-natural ecosystems, solid lines represent grasslands and star marked lines represent arable crops. The top x-axis represents the corresponding vapour pressure deficit (VPD) for the primary $\mathrm{x}$-axis at a temperature of $10^{\circ} \mathrm{C}$. Different colours represent the corresponding molar ratio of total acid/NH 3 (AR). Numbers correspond to Table 1 .

\subsection{Stomatal compensation point $\left(\chi_{\mathrm{s}}\right)$}

The stomatal compensation point $\left(\chi_{\mathrm{s}}\right)$ is expected to be dependent on the nitrogen status of the plant, which in return is related to the influx of $\mathrm{N}$ based compounds ( $\mathrm{N}$ fertilisation or atmospheric deposition) (Mattsson et al., 1998; van Hove et al., 2002). $\chi_{\mathrm{s}}$ is further influenced by the developmental stage and may peak at senescence (Francis et al., 1997; Hill et al., 2002; Mattsson and Schjoerring, 2003). Several attempts have been made to model the dynamics of $\chi_{\mathrm{s}}$ mechanistically, for example in relation to environmental conditions, agricultural practices, plant metabolism and/or exchange with the atmosphere (Riedo et al., 2002; Wu et al., 2009; Massad et al., 2010). While $\mathrm{N}$ input is likely to be the first order driver, values of $\chi_{\mathrm{s}}$ have been found to differ significantly between different plant species growing in the same sward (Mattsson et al., 2009b). Our understanding of the plant physiological controls of $\chi_{\mathrm{s}}$ is still too rudimentary to explain this inter-species variability.

One of the major challenges in quantifying vegetationatmosphere fluxes of $\mathrm{NH}_{3}$ is the measurement of $\chi_{\mathrm{s}}$. Three methods were developed so far that allow its estimation.

1. Micrometeorological flux measurements. Inference of the stomatal compensation point from fluxes over large fields and concentrations in the atmosphere (e.g., Flechard, 1998; Spindler et al., 2001). This technique allows estimation of $\chi_{c}$ for conditions where the flux is zero (e.g., flux changing in time from deposition to emission or vice versa). In situations where $R_{\mathrm{w}}$ is thought to be very large (e.g., dry canopy, low relative humidity) and $R_{\mathrm{S}}$ and the flux are small, $\chi_{\mathrm{c}}$ will approach $\chi_{\mathrm{s}}$. In other studies, $\chi_{\mathrm{s}}$ values have been de- rived by fitting diurnal cycles of the modelled flux to measured values, based on prior parameterisation of $R_{\mathrm{w}}$ (Sutton and Fowler, 1993; Sutton et al., 1995b; Sutton et al., 1998a).

2. Controlled gas exchange measurements. Calculation of $\chi_{\mathrm{c}}$ for plants enclosed in a cuvette by varying the $\mathrm{NH}_{3}$ concentration at the entrance of the cuvette and finding the concentration at which the total flux is zero (e.g., Farquhar et al., 1980; Husted and Schjoerring, 1995a; Schjoerring et al., 1998a; Hill et al., 2001). Measurements are typically made during light conditions with open stomata and low RH (large $R_{\mathrm{w}}$ ). However, fluxes measured in the dark in this approach can also be used to estimate the role of cuticular exchange. Errors related to chamber measurements include separation of the cuticular and stomatal fluxes and the calculation of total resistance to $\mathrm{NH}_{3}$ exchange (calculation of $R_{\mathrm{a}}$ and $R_{\mathrm{b}}$ ) within the cuvette, especially at higher RH (Massad et al., 2009).

3. Apoplastic extraction. Direct determination of leaf apoplastic $\left[\mathrm{NH}_{4}^{+}\right]_{\text {apo }}$ concentration and $\mathrm{pH}$ by means of extraction of the apoplastic fluid with successive vacuum infiltration and centrifugation of leaf segments (Husted and Schjoerring, 1995b). This technique has been applied to several plant species in the field (Husted et al., 2000a; Herrmann et al., 2009; Mattsson et al., 2009a; Mattsson et al., 2009b). However, the extraction technique is subject to uncertainties regarding potential regulation of apoplastic $\mathrm{pH}$ and $\left[\mathrm{NH}_{4}^{+}\right]_{\text {apo }}$ by the plant during the extraction, buffering effects and potential local gradients of $\mathrm{pH}$ and $\left[\mathrm{NH}_{4}^{+}\right]_{\text {apo }}$ in the apoplast 
but also inter-species gradients of $\chi_{\mathrm{s}}$ (Hill et al., 2001; Loubet et al., 2002; Schjoerring et al., 2002, Sutton et al., 2009a). Systemic differences between apoplast extraction and the gas exchange techniques were reported (Hill et al., 2001, Massad et al., 2009), these are attributed to errors in both methods and should be further investigated.

The ratio of $\left[\mathrm{NH}_{4}^{+}\right]_{\text {apo }}$ to $\left[\mathrm{H}^{+}\right]_{\text {apo }}$ concentration in the apoplast $\left(\Gamma_{\mathrm{s}}\right)$, can be calculated from extraction measurements as well as from flux measurements. The equation relating $\chi_{\mathrm{s}}$ to $\Gamma_{\mathrm{s}}$ according to Nemitz et al. (2001) is:

$\chi_{\mathrm{s}}=\frac{161500}{T_{l}} \times 10^{\frac{-10380}{T_{l}}} \times \Gamma_{\mathrm{s}}$

where $T_{l}$ is the leaf temperature. $\Gamma_{\mathrm{s}}$ therefore represents a useful parameter for comparison between the three estimation techniques, as it is unitless and temperature independent (from a chemical thermodynamic perspective). $\Gamma_{\mathrm{s}}$ reflects the physiological state of the vegetation, while $\chi_{\mathrm{s}}$ also depends on meteorological parameters (temperature). For this reason we base our parameterisation on values of $\Gamma_{\mathrm{s}}$ directly rather than on $\chi_{\mathrm{s}}$.

\subsection{Ground layer compensation point $\left(\chi_{\mathrm{g}}\right)$}

Similar to the leaf apoplast solution, the equilibrium between gaseous $\mathrm{NH}_{3}$ in the soil pore space and $\mathrm{NH}_{4}^{+}$in the soil solution establishes a soil compensation point $\left(\chi_{\mathrm{g}}\right)$ (Nemitz et al., 2001).A soil emission potential $\left(\Gamma_{\mathrm{g}}\right)$ can be calculated from $\chi_{\mathrm{g}}$ using the same approach as in leaf apoplast or by applying Eq. (5). The ground layer compensation point can be attributed to the litter or to the soil, or both. There are few reported measurements of ground layer emission potentials $\left(\Gamma_{\mathrm{g}}\right)$ especially for bare soils and litter. Nemitz et al. (2001) modelled the litter emission potential based on measurements of $\left[\mathrm{NH}_{4}^{+}\right] /\left[\mathrm{H}^{+}\right]$ratio in bulk tissue extracts and on the mineralization and nitrification rates to simulate the $\mathrm{NH}_{3}$ cycling within an oilseed rape canopy. Concerning the soil emission potential, one should differentiate between fertilised and non-fertilised soils. Unfertilised soils have seldom been shown to have a $\Gamma_{\mathrm{g}}$ larger than $\Gamma_{\mathrm{s}}$ (Schjoerring et al., 1993; Sutton et al., 1993b; Nemitz et al., 2000a), whereas fertilised soils have very high emission potentials especially in the days following fertiliser application. These include direct emissions from the mineral or organic fertilisers. Nemitz et al. (2000b) report measurements over a wheat stubble estimating a $\Gamma_{\mathrm{g}}$ value of 630 which corresponds to the ratio of $\left[\mathrm{NH}_{4}^{+}\right]$to $\left[\mathrm{H}^{+}\right]$measured in the soil solution. Numerous models exist that account for the physico-chemical processes controlling $\mathrm{NH}_{3}$ emission from fertilisers and their interactions with the soil (e.g. Génermont and Cellier, 1997; Cooter et al., 2010) and are being integrated into atmospheric transport models (Cooter et al., 2010).

A recent comparison of $\Gamma$ values for different plant and soil compartments in a managed cut grassland showed val- ues ranging over four orders of magnitude, with the smallest values being for $\Gamma_{\mathrm{s}}$ (Sutton et al., 2009a). That analysis indicated that, following cutting, when litter elements are exposed and well connected to the atmosphere, $\Gamma_{\text {litter }}$ would be a better descriptor of net exchange than $\Gamma_{\mathrm{s}}$, warranting further efforts into the parameterisation of litter dynamics.

\section{Review of compensation point published datasets}

Table 2 summarises 60 values of $\Gamma_{\mathrm{s}}$ for non-managed ecosystem types (short semi-natural and forest) ranging between 3 and 5604, with a mean of 502 and a median of 190, while Table 3 summarises 96 values of $\Gamma_{\mathrm{s}}$ for managed ecosystems (arable and grassland) outside fertilisation events ranging between 16 and 5233, with a mean of 782 and a median of 416. The highest $\Gamma_{\mathrm{s}}$ value was derived for a forest ecosystem whereas the lowest value corresponds to nonmanaged grassland. However, Sutton et al. (1997) report a $\Gamma_{\mathrm{s}}$ value of 10000 for a managed grassland, which occurred two weeks after a fertilisation event. The surprisingly high $\Gamma_{\mathrm{s}}$ value for the forest ecosystem is attributed to Wyers and Erisman (1998). This value was probably subject to a contribution from cuticular desorption rather than just reflecting stomatal emission, consistent with more recent interpretations by Neirynck and Ceulmans (2008) over a similar forest. This value apart, the highest $\Gamma_{\mathrm{s}}$ is reported for arable crops. For the compiled data, none of the three measurement methods gave a tendency towards higher or lower values compared with the other. However, the gas exchange measurements seem to give higher $\Gamma_{\mathrm{s}}$ values for semi-natural vegetation but this is probably due to measurements being done in high $\mathrm{N}$ input semi-natural ecosystems. Figure 3 presents the assembled data relative to each ecosystem type: arable (mainly wheat, barley, oilseed rape and maize), grassland (managed), short semi-natural vegetation (unmanaged grassland, heathland, etc.) and forest. Data are also grouped according to measurement technique.

Elevated values of $\Gamma_{\mathrm{s}}$ have been derived for Dutch and Belgian semi-natural ecosystems, which are subject to considerable $\mathrm{N}$ deposition, and fertilised vegetation tends to have larger values of $\Gamma_{\mathrm{s}}$ than non-fertilised vegetation. This confirms that the likely key factor affecting $\Gamma_{\mathrm{s}}$ appears to be the $\mathrm{N}$ input to the ecosystem, and this is also consistent with existing ecosystem models that attempt to predict $\Gamma_{\mathrm{s}}$. The $\mathrm{N}$ input is dominated by atmospheric deposition of reactive nitrogen $\left(N_{\mathrm{dep}}\right)$ in natural ecosystems surrounded by highly polluted areas (Sutton et al., 1994; Dijk et al., 2009) or N fertilisation in agricultural ecosystems (Mattsson and Schjoerring, 1996; Mattsson et al., 2009a). Field fertiliser application results in a peak in $\Gamma_{\mathrm{s}}$ in the days following the application and usually returns to the pre-fertilisation value one to two weeks later depending on meteorological conditions (Milford et al., 2001b; Mattsson and Schjoerring, 2002). 


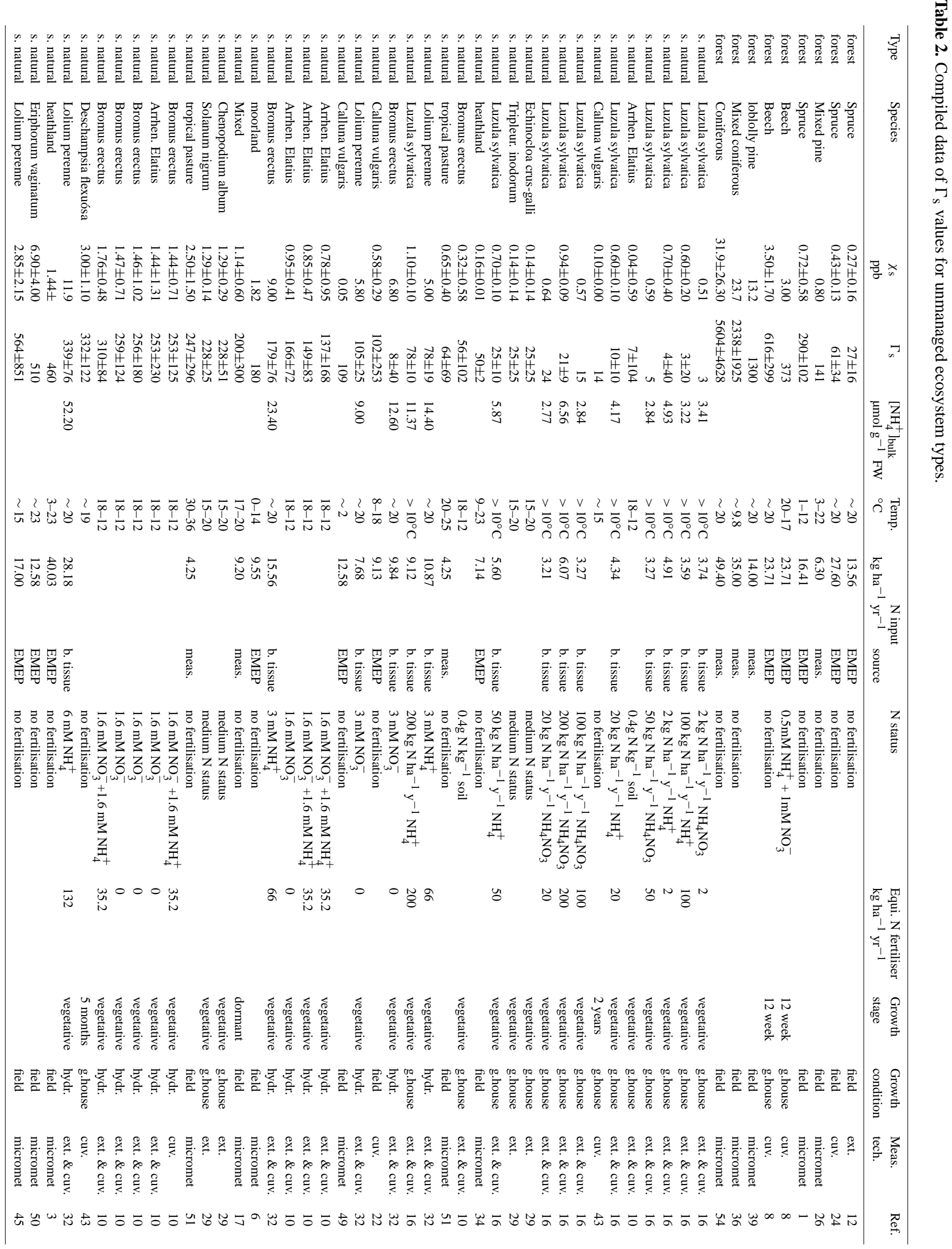




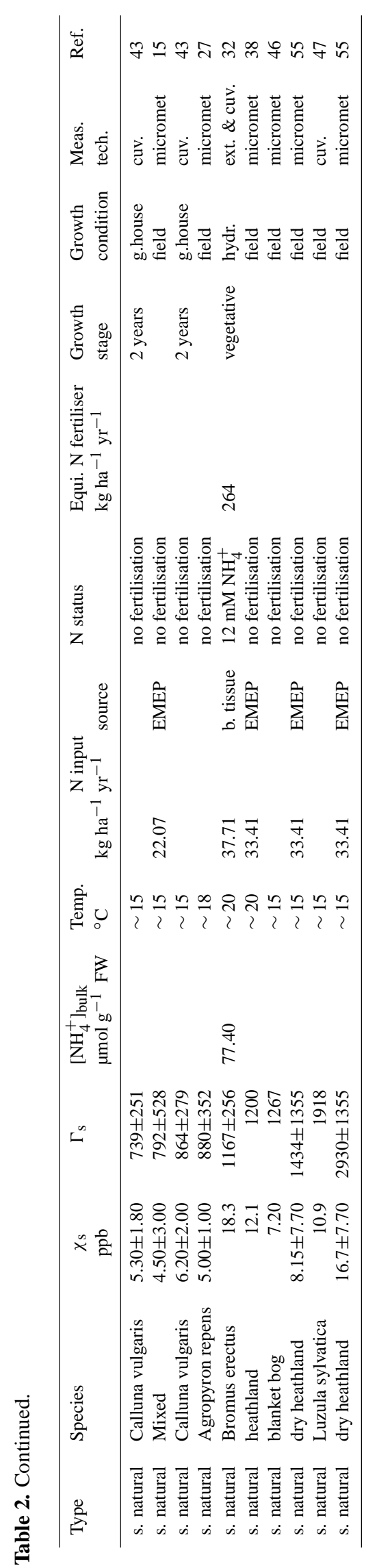

Measurements further suggest that $\Gamma_{\mathrm{S}}$ is affected by the plant's stage of growth. This is especially true for agricultural crops where senescent and mature leaves have a high potential for $\mathrm{NH}_{3}$ emission (Mattsson and Schjoerring, 2003). In grassland ecosystems cutting as well as grazing are reported to affect $\Gamma_{\mathrm{c}}$. Due to additional remobilisation from urine and dung, grazing can be considered as an additional $\mathrm{N}$ source for the grassland as regards ammonia emission. By contrast, cutting seems to affect $\Gamma_{\mathrm{c}}$ because it (i) prevents the recapture of $\mathrm{NH}_{3}$ emitted from the litter (Sutton et al., 2009a), (ii) exposes the litter to higher temperatures (David et al., 2009; Personne et al., 2009; Sutton et al., 2009a) and (iii) alters the metabolism of the plant, possibly affecting emissions through injuries to the leaves (Milford et al., 2009) and reducing consumption of substrate $\mathrm{N}$ into structural $\mathrm{N}$ in the plant (Riedo et al., 2002).

\subsection{Relationship between $\Gamma_{\mathrm{s}}$ and bulk foliar ammonium concentrations}

Given the complexity of determining $\Gamma_{\mathrm{s}}$ from bioassays (Husted and Schjoerring, 1996; Hill et al., 2001; Massad et al., 2009), there is significant interest in using bulk foliar $\left[\mathrm{NH}_{4}^{+}\right]$concentration $\left(\left[\mathrm{NH}_{4}^{+}\right]_{\text {bulk }}\right.$ ) as a simpler proxy bioassay of the compensation point. Bulk tissue $\left[\mathrm{NH}_{4}^{+}\right]$is easier to measure than apoplastic $\left[\mathrm{NH}_{4}^{+}\right]_{\text {apo }}$ and may be an easier way to estimate $\mathrm{NH}_{3}$ exchange between the vegetation and the atmosphere. Mattsson et al. (2009b) found a linear relationship between $\left[\mathrm{NH}_{4}^{+}\right]_{\text {bulk }}$ and $\Gamma_{\mathrm{s}}$ across grass species growing within a single sward. The larger dataset compiled here allows the relationship between $\Gamma_{\mathrm{s}}$ and $\left[\mathrm{NH}_{4}^{+}\right]_{\text {bulk }}$ to be assessed more comprehensively. Figure $4 \mathrm{a}$ shows the data for managed ecosystem types. Using the full range of data, there appears to be an exponential rather than a linear relationship between the two variables, where $\Gamma_{\mathrm{s}}$ tends to increase much more than $\left[\mathrm{NH}_{4}^{+}\right]_{\text {bulk. }}$. This can be explained by the biological regulation of cytoplasmic $\left[\mathrm{NH}_{4}^{+}\right]$which is well buffered as compared to physical and chemical regulation of apoplastic $\left[\mathrm{NH}_{4}^{+}\right]$(Nielsen and Schjoerring, 1998). The exponential fitted equation to these data is:

$\Gamma_{\mathrm{S}}=19.3 \times e^{\left(0.0506 \times\left[\mathrm{NH}_{4}^{+}\right]_{\text {bulk }}\right)}$

where $\left[\mathrm{NH}_{4}^{+}\right]_{\text {bulk }}$ is in $\mu \mathrm{g} \mathrm{g}^{-1}$ tissue fresh weight and $\Gamma_{\mathrm{s}}$ is unitless. The difference between the linear regression proposed by Mattsson et al. (2009b) and the exponential equation proposed in this study can partly be explained by the difference in landuse type. The Mattsson et al. (2009b) data is for grasslands whereas the fitted equation in this study is derived for both arable land and grassland data; with grassland data being more scattered and corresponding to lower $\left[\mathrm{NH}_{4}^{+}\right]_{\text {bulk }}$.

For semi-natural vegetation there are far fewer direct paired measurements of $\Gamma_{\mathrm{s}}$ and $\left[\mathrm{NH}_{4}^{+}\right]_{\text {bulk }}$ (Fig. 4b). However, Pitcairn et al. (2004) proposed a relationship between 


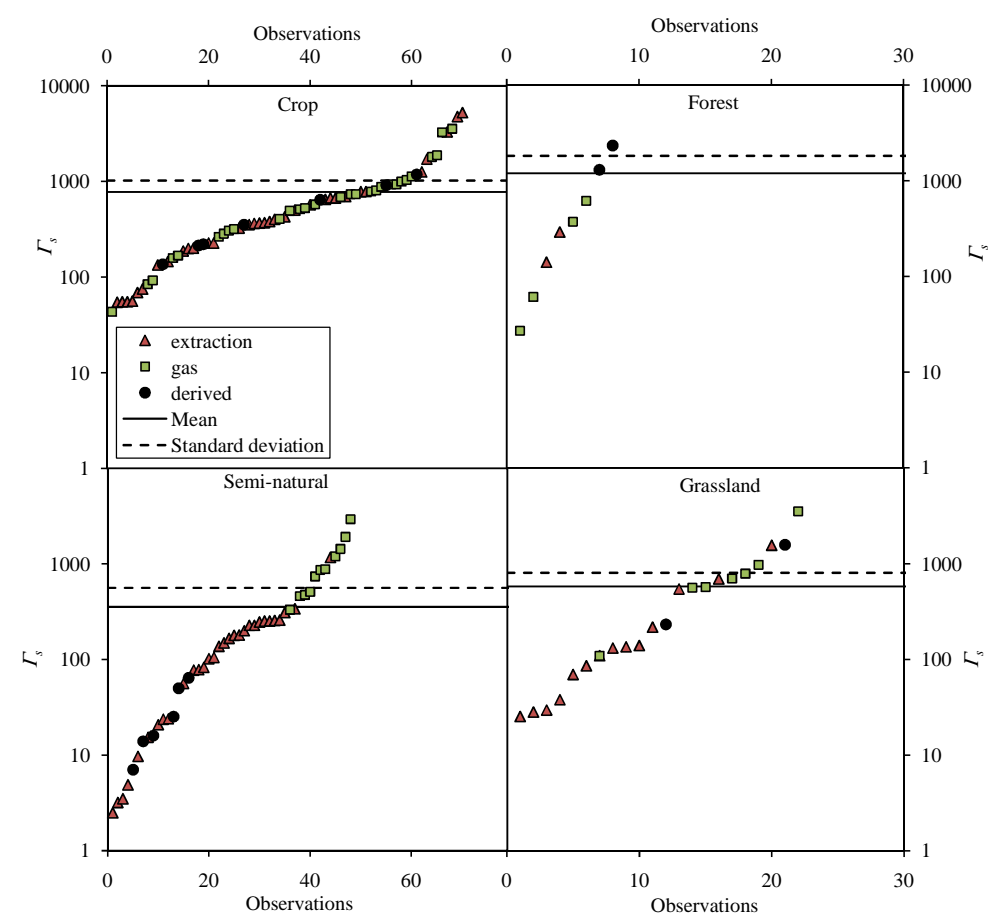

Fig. 3. Summary of stomatal ammonia emission potential $\left(\Gamma_{\mathrm{s}}\right)$ from different studies (see Tables 2 and 3 ) as reported in the literature (means or single measurements) separated according to ecosystem type. Round symbols represent values derived from modelling, triangles represent values measured by the apoplast extraction technique and squares represent values measured by the gas exchange method. Full lines represent the mean and dashed lines the standard deviation around the mean per ecosystem type.

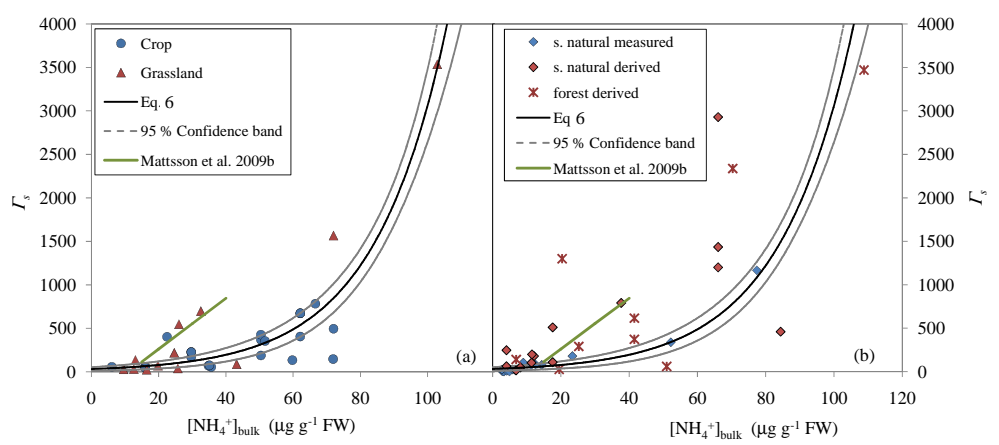

Fig. 4. (a) Compiled stomatal ammonia emission potential $\left(\Gamma_{\mathrm{s}}\right)$ for managed ecosystem types as a function of measured bulk tissue $\left[\mathrm{NH}_{4}^{+}\right]_{\text {bulk }}$ concentrations. Round symbols represent arable crops and triangle symbols represent grasslands. The black line is the best fit exponential curve derived by minimisation of the least square method and the dashed line is the $95 \%$ confidence band. The green line is the linear function previously derived by Mattsson et al. (2009b) between $\Gamma_{\mathrm{s}}$ and $\left[\mathrm{NH}_{4}^{+}\right]_{\text {bulk }}$ for different grass species. (b) Compiled stomatal ammonia emission potential $\left(\Gamma_{\mathrm{s}}\right)$ for un-managed ecosystem types as a function of bulk tissue $\left[\mathrm{NH}_{4}^{+}\right]_{\text {bulk }}$ concentrations. Red symbols represent $\left[\mathrm{NH}_{4}^{+}\right]_{\text {bulk }}$ derived from $\mathrm{N}$ deposition values according to Eq. (7) while blue symbols represent measured concentrations. Asterisks represent forests and diamonds represent short semi-natural ecosystem types. The full, dashed and green lines are similar to (a).

$\left[\mathrm{NH}_{4}^{+}\right]_{\text {bulk }}$ and total $\mathrm{N}$ deposition, which may be inverted to estimate $\left[\mathrm{NH}_{4}^{+}\right]_{\text {bulk }}$ for additional measurements, for which an $\mathrm{N}$ deposition estimate is available:

$N_{\text {dep }}=1.51 \times\left(\left[\mathrm{NH}_{4}^{+}\right]_{\text {bulk }}\right)^{0.739}$
Here, $N_{\text {dep }}$ is the total atmospheric $\mathrm{N}$ deposition in $\mathrm{kg} \mathrm{ha}^{-1} \mathrm{yr}^{-1}$ and $\left[\mathrm{NH}_{4}^{+}\right]_{\text {bulk }}$ is in $\mu \mathrm{g} \mathrm{g}^{-1}$ tissue fresh weight. These additional, derived data have been added to Fig. 4b to see how they compare to managed ecosystems. This figure shows estimated and measured $\left[\mathrm{NH}_{4}^{+}\right]_{\text {bulk }}$ for unmanaged ecosystems as a function of $\Gamma_{\mathrm{s}}$. We note that although there is 
a larger uncertainty in $\left[\mathrm{NH}_{4}^{+}\right]_{\text {bulk }}$ estimates coming from both $N_{\text {dep }}$ values and applying a site and species specific derived equation (Eq. 7), they compare well to the fitted relationship for managed ecosystems. In particular, these additional values also support the choice of the non-linear fitted function type.

These results imply that the relationship between $\Gamma_{\mathrm{s}}$ and $\left[\mathrm{NH}_{4}^{+}\right]_{\text {bulk }}$ is relatively robust across a wide range of plant species. The relationship of Eq. (6) enables us to extend the application of ecosystem or dynamics crop models to sites where only information is available on the plants $\mathrm{N}$ status, but not on $\Gamma_{\mathrm{s}}$. The use of this equation in atmospheric chemistry and transport models is more problematic, because spatial input fields of $\mathrm{N}$ status are not generally available. It is more convenient to link $\Gamma_{\mathrm{s}}$ to a more accessible variable.

\subsection{Dependence of long term $\Gamma_{\mathrm{s}}$ values on $\mathrm{N}$ inputs}

As discussed above, in most non-agricultural ecosystems, the major source of $\mathrm{N}$ is atmospheric deposition $\left(N_{\mathrm{dep}}\right)$. Figure $5 \mathrm{a}$ and $\mathrm{c}$ show the plot of compiled $\Gamma_{\mathrm{s}}$ values versus total $\mathrm{N}$ input for forest and short semi-natural ecosystems on a linear and logarithmic scale, respectively. We notice that $\Gamma_{\mathrm{s}}$ increases considerably with $\mathrm{N}$ input (power function). Atmospheric deposition represents an estimate of wet and dry deposition of reduced and oxidized forms of N. For field studies, $N_{\text {dep }}$ was derived either from direct measurements or taken from the results of a European atmospheric transport model (EMEP Unified model run for the year the $\Gamma_{\mathrm{s}}$ measurements were made for, $N_{\text {dep }}$ values on a grid basis, Simpson et al., 2003, 2006). Nitrogen deposition values on a grid basis are significantly different from ecosystem specific values in some cases and are an additional source of uncertainty in this study. For many laboratory experiments, total $\mathrm{N}$ input had to be estimated from $\left[\mathrm{NH}_{4}^{+}\right]_{\text {bulk }}$ according to Eq. (7). The values are listed in Table 3, together with their mode of calculation. With the exception of two studies (16: Hill et al., 2001; 32: Mattsson and Schjoerring, 2002), the total $\mathrm{N}$ input is in the form of atmospheric deposition. We notice that the laboratory experiments clearly differentiate from the rest of the data points which could be due to the large uncertainty resulting from the calculation of total $\mathrm{N}$ input. The lack of correlation can also be explained by the fact that:

- These data points are in the majority semi-natural vegetation that was transposed to the laboratory and watered with high $\mathrm{N}$ solution for a short time interval. One can think that in the case of semi-natural vegetation an adaptation time is required for the high $\mathrm{N}$ input to be reflected in $\Gamma_{\mathrm{s}}$.

- These data points are for a range of different plant species and as shown by Mattsson et al. (2009), there is an important interspecies variability in $\Gamma_{\mathrm{s}}$.
- On top of the uncertainty in the estimation of the total $\mathrm{N}$ input to the experimental setup there is an uncertainty in the measurement of $\Gamma_{\mathrm{s}}$ especially that this was done with different methods (gas exchange vs. apoplast extraction).

We therefore chose to exclude the data points concerning laboratory conducted experiments where $\mathrm{N}$ input to the ecosystem was derived from $\left[\mathrm{NH}_{4}^{+}\right]_{\text {bulk }}$ from the parameterisation. The best fit equation to the measured data is the following power curve:

$\Gamma_{\mathrm{s}}=246+(0.0041) \times\left(N_{\text {in }}\right)^{3.56}$

where $N_{\text {in }}$ is in $\mathrm{kg} \mathrm{N} \mathrm{ha}^{-1} \mathrm{yr}^{-1}$.

With the exception of the period right after fertilisation events, $\Gamma_{\mathrm{s}}$ in managed ecosystems should also be related to the average $\mathrm{N}$ status which is mainly related to the long-term (e.g., annual) fertiliser input. Figure $5 \mathrm{~b}$ and d show the relation between $\Gamma_{\mathrm{s}}$ and total $\mathrm{N}$ input to the ecosystem (annual $\mathrm{N}$ fertilisation rate plus atmospheric $\mathrm{N}$ input values derived from Eq. 7). It should be noted that data points for which both of those variables ( $\mathrm{N}$ input and $\mathrm{N}$ fertilisation rate) could not be derived were not accounted for in the parameterisation. The major $\mathrm{N}$ source for most of those studies is the fertiliser application; therefore the uncertainty resulting from the estimation of atmospheric $\mathrm{N}$ deposition is negligible. The data for managed ecosystem may be described by:

$\Gamma_{\mathrm{s}}=66.4+(0.0853) \times\left(N_{\text {in }}\right)^{1.59}$

where $N_{\text {in }}$ is the total $\mathrm{N}$ input to the ecosystem (fertilisation and atmospheric deposition) in $\mathrm{kg} \mathrm{ha}^{-1} \mathrm{yr}^{-1}$. As with the data on the unmanaged ecosystems, this relation does not explain the entire scatter in the data (adjusted $R^{2}=0.36$ ). One of the possible reasons is linked to the uncertainties in estimating total yearly fertiliser $\mathrm{N}$ application from hydroponics and pot experiments where $\mathrm{N}$ addition are not expressed as $\mathrm{kg} \mathrm{N} \mathrm{ha}^{-1} \mathrm{yr}^{-1}$. But it is also consistent with the interspecies variability within a single grass sward as reported by Mattsson et al. (2009b).

Comparison of Fig. 5a and b demonstrates clearly that for managed ecosystems an almost 10 times larger $\mathrm{N}$ input is required to generate the same $\Gamma_{\mathrm{s}}$. This suggests that seminatural vegetation may be less adapted to using large supplies of nitrogen and becomes nitrogen saturated at lower levels, whereas arable crops and agricultural grassland species have been genetically selected to have a higher $\mathrm{N}$ use efficiency resulting in lower soluble $\left[\mathrm{NH}_{4}^{+}\right]$both in the apoplastic fluid and in the total bulk tissue.

\subsection{Dynamics in $\Gamma_{\mathrm{s}}$ after fertilisation}

While $\Gamma_{\mathrm{s}}$ was found to be linked to annual $\mathrm{N}$ input for periods outside of the first 2-3 weeks following a fertilisation event, it is likely that directly after fertilisation it is more linked to the amount and type of fertiliser of the event itself, 


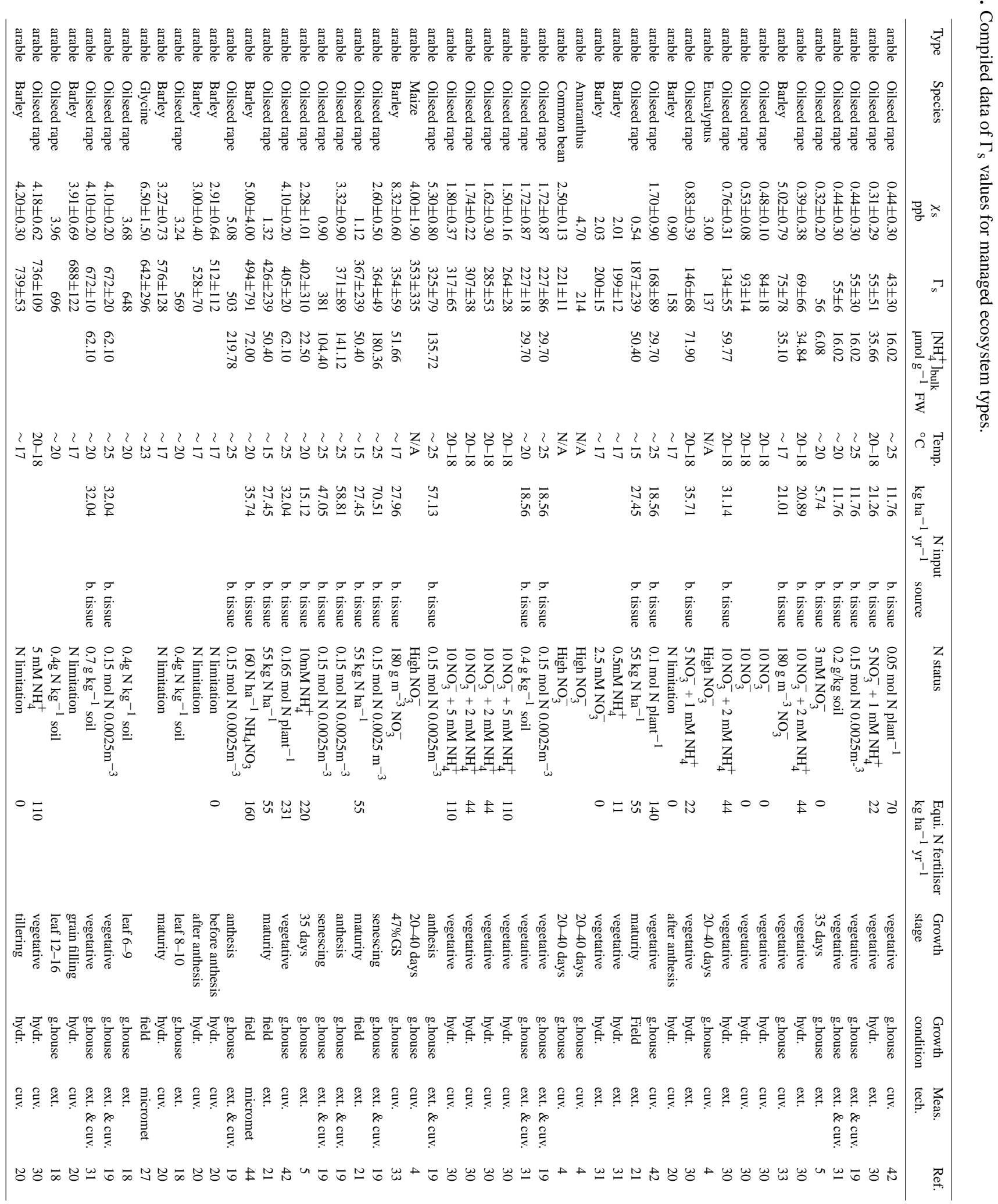




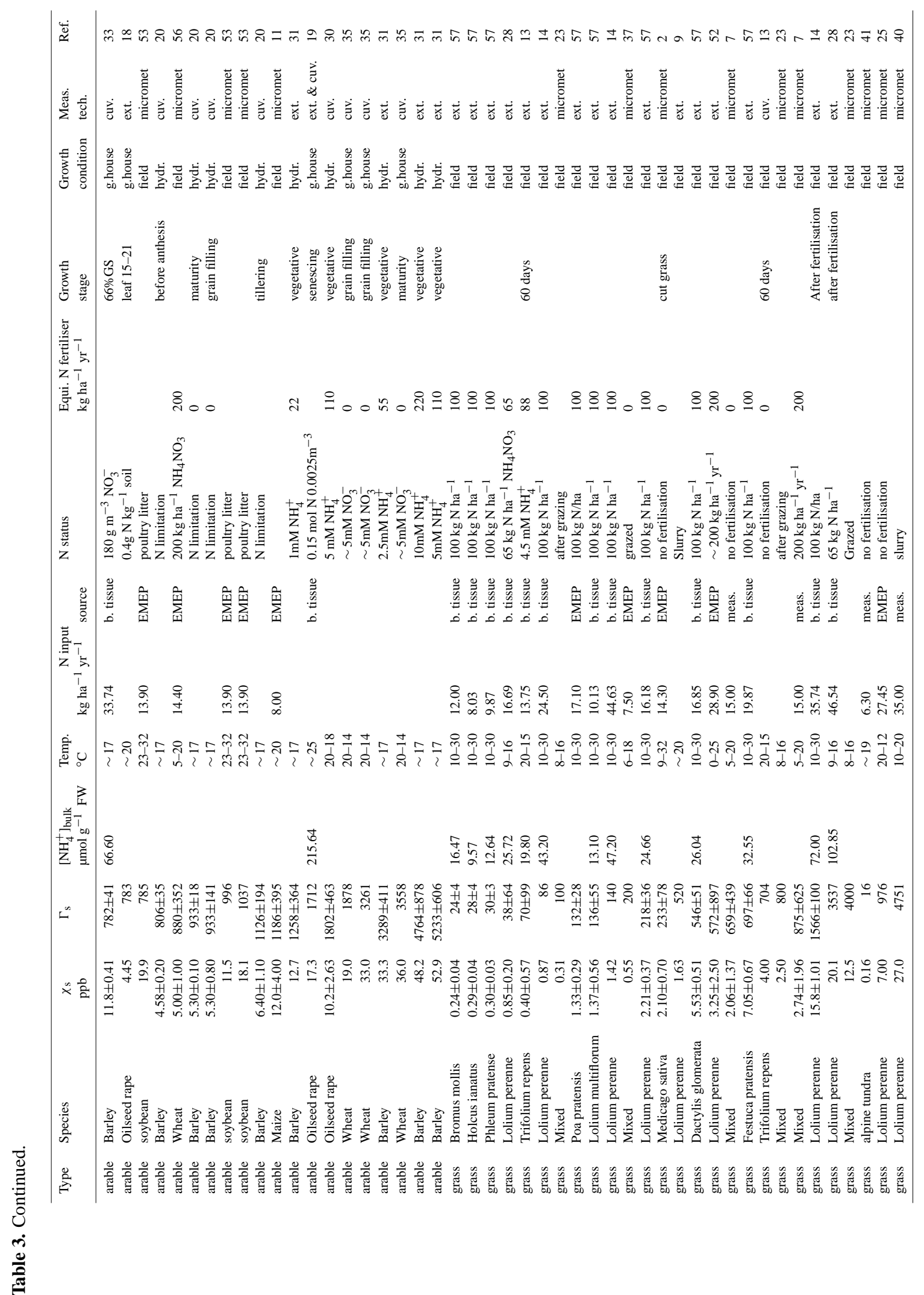

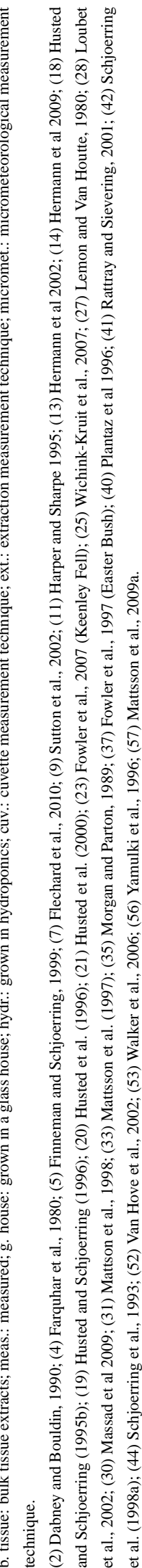



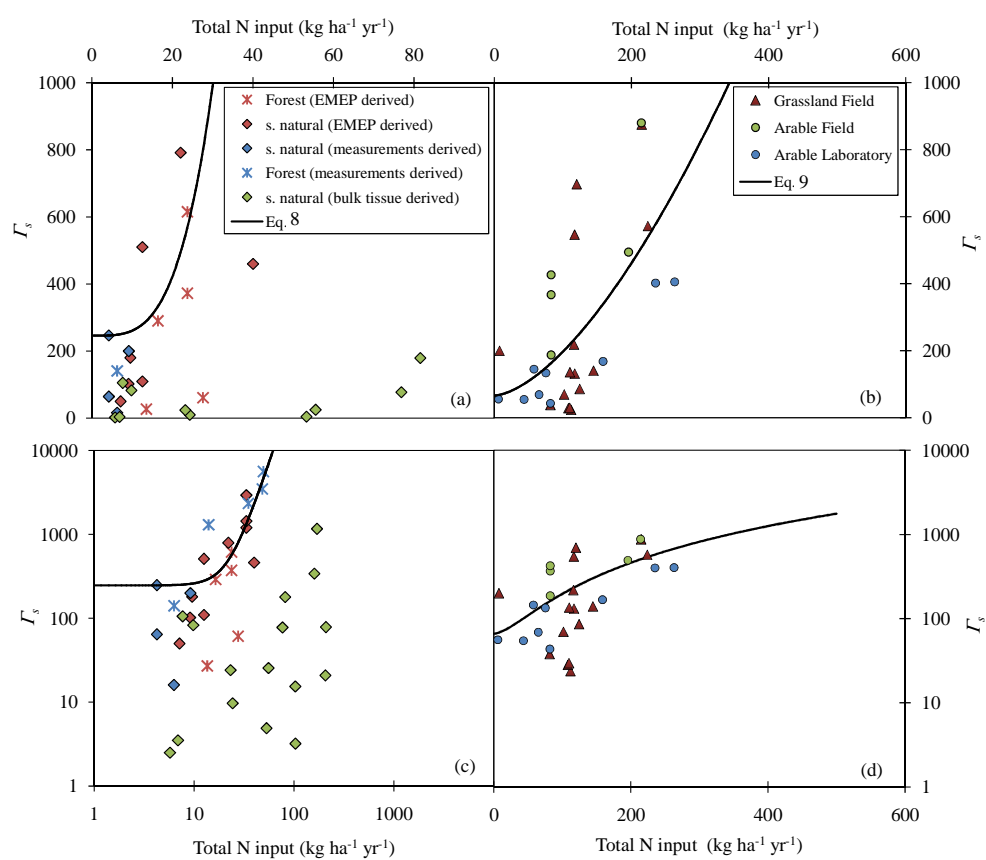

Fig. 5. (a) and (c) Compiled stomatal ammonia emission potential $\left(\Gamma_{\mathrm{s}}\right)$ for non-managed ecosystem types as a function of total $\mathrm{N}$ input to the ecosystem on a linear and logarithmic scale respectively. Data are separated according to the data source of the $N_{\text {in }}$ value (EMEP model estimated, site-based measurements and bulk tissue derived values according to Eq. 7). Red and blue symbols have only atmospheric deposition as an $\mathrm{N}$ source and green symbols have atmospheric deposition as well as fertiliser as $\mathrm{N}$ source. The line is the best fit power function derived by minimisation of the least square method excluding data for laboratory based experiments (green symbols) (refer to text). (b) and (d) Compiled stomatal ammonia emission potential $\left(\Gamma_{\mathrm{S}}\right)$ for managed ecosystem types as a function of total $\mathrm{N}$ input on a linear and logarithmic scale respectively. The black line is the best fit equation to the data points. Red triangles represent field grassland measurements, green and red circles represent field based and laboratory based measurements on arable crops respectively. Approximated fertiliser $\mathrm{N}$ input values for laboratory based experiments are given in Table 3.

the application technique and soil and weather conditions. Measurements including fertiliser application include plants grown in soil and those grown in hydroponic solution. It is worth noting that the data analysed for $\Gamma_{\mathrm{s}}$ directly following fertilisation events are only for measurements done using the apoplast extraction technique since the flux measurement technique would give $\Gamma_{\mathrm{c}}$ for the whole canopy (plant and soil). Figure 6a shows $\Gamma_{\mathrm{s}}$ versus fertiliser application (primary $\mathrm{x}$-axis) the first day after application and $\left[\mathrm{NH}_{4}^{+}\right]$concentration in the nutritive solution (secondary $\mathrm{x}$-axis). We note a linear relation between $\Gamma_{\mathrm{s}}$ and the amount of fertiliser applied for both plants grown in soil and in hydroponics. Some of the $\Gamma_{\mathrm{s}}$ values for plants grown in hydroponics have a different slope than the others (Mattsson et al., 1998). In that particular study, the higher $\Gamma_{\mathrm{s}}$ values for plants grown with $5 \mathrm{mM} \mathrm{NH}_{4}^{+}$in the nutritive solution relative to those grown with $10 \mathrm{mM} \mathrm{NH}_{4}^{+}$are due to a lower $\mathrm{pH}$ and not to higher $\left[\mathrm{NH}_{4}^{+}\right]_{\text {apo }}$ concentrations in the apoplast. We also note that for plants grown in hydroponics, $\Gamma_{\mathrm{s}}$ is more strongly correlated to the $\mathrm{NH}_{4}^{+}$concentration in the nutritive solution than the $\mathrm{NO}_{3}^{-}$concentrations (Mattsson et al., 1998; Massad et al., 2009). If we assume for the compiled $\Gamma_{\mathrm{s}}$ data that plants grown in hydroponics respond in the same way as plants grown in the field to $\mathrm{N}$ application then we can equate the two linear regressions (between $\Gamma_{\mathrm{s}}$ and $\left[\mathrm{NH}_{4}^{+}\right]$in the nutritive solution on one hand and $\Gamma_{\mathrm{s}}$ and total $\mathrm{N}$ in the fertiliser applied on the second). One $\mathrm{mM} \mathrm{NH}_{4}^{+}$in the nutritive solution can then be approximated to $22 \mathrm{~kg} \mathrm{ha}^{-1}$ of applied $\mathrm{N}$ fertilisation. Although significant uncertainties lie around this approximation, it is a useful practical approach for grouping laboratory and field based experiments.

$\Gamma_{\mathrm{s}}$ dynamics after fertilisation were measured in several studies. These measurements are shown in Fig. 6b. We notice a return to pre-fertilisation $\Gamma_{\mathrm{s}}$ values in the 10 days that follow fertiliser application. The only exception in the compiled data was the study on the Dutch GRAMINAE site (Sutton et al., 2002) where the peak in $\Gamma_{\mathrm{s}}$ only appeared 2 days later. This could be explained by the fact that in this case the fertiliser applied was in the form of manure which can take time to become available to the plant.

\subsection{Dynamics in $\Gamma_{\mathrm{g}}$ after fertilisation}

Table 4 summarises existing values of $\Gamma_{\mathrm{g}}$ for ground layer measurements. Those include bare soil, leaf litter and soil 
Table 4. Compiled data of $\Gamma_{\mathrm{g}}$ values.

\begin{tabular}{|c|c|c|c|c|c|c|c|c|}
\hline Type & Species & Specifications & $\begin{array}{l}\chi_{\mathrm{g}} \\
\mathrm{ppb}\end{array}$ & $\Gamma_{\mathrm{g}}$ & $\begin{array}{l}\text { Average temp. } \\
{ }^{\circ} \mathrm{C}\end{array}$ & $\mathrm{N}$ status & $\begin{array}{l}\text { Meas. } \\
\text { tech. }\end{array}$ & Reference \\
\hline grassland & Mixed & Cut grassland & 434 & 85800 & 19 & $300 \mathrm{~kg} \mathrm{ha}^{-1}$ & ext. & David et al., 2009 \\
\hline grassland & Mixed & Tall Grassland & 313 & 61900 & 19 & $300 \mathrm{~kg} \mathrm{ha}^{-1}$ & ext. & David et al., 2009 \\
\hline grassland & Mixed & Cut grassland, with hay & 429 & 84900 & 19 & $300 \mathrm{~kg} \mathrm{ha}^{-1}$ & ext. & David et al., 2009 \\
\hline grassland & Mixed & Bare soil & 530 & 104900 & 19 & $300 \mathrm{~kg} \mathrm{ha}^{-1}$ & ext. & David et al., 2009 \\
\hline grassland & Mixed & Bare soil and litter & 384 & 76000 & 19 & $300 \mathrm{~kg} \mathrm{ha}^{-1}$ & ext. & David et al., 2009 \\
\hline grassland & Mixed & slurry & $4900-36000$ & $\begin{array}{l}8.5 \times 10^{5}- \\
6.3 \times 10^{6}\end{array}$ & 20 & & ext. & Flechard et al., 2010 \\
\hline grassland & Mixed & Bare soil & 2 & 360 & 19 & no fertilisation & ext. & David et al., 2009 \\
\hline arable & Brassica napus & litter & 10 & 3431 & 14 & $285 \mathrm{~kg} \mathrm{ha}^{-1} \mathrm{yr}^{-1}$ & ext. & Husted et al., 2000 \\
\hline arable & Soybean/wheat/maize & & 74 & 13000 & 20 & no fertilisation & ext. & Walker et al., 2008 \\
\hline arable & Soybean/wheat/maize & & 9 & 1514 & 20 & swine manure & ext. & Walker et al., 2008 \\
\hline arable & wheat stubble & & 8 & 1450 & 20 & no fertilisation & micromet. & Neftel et al., 1998 \\
\hline arable & wheat stubble & & 2 & 630 & 15 & no fertilisation & model & Nemitz et al., 2001 \\
\hline arable & wheat & & 44 & 7742 & 20 & no fertilisation & extr. & Fang et al., 2006 \\
\hline arable & Brassica napus & & $17-74$ & $3000-13000$ & 20 & $285 \mathrm{~kg} \mathrm{ha}^{-1} \mathrm{yr}^{-1}$ & model & Nemitz et al., 2000b \\
\hline semi-natural & Lolium perenne & senescing excised & 142 & 25000 & 20 & no fertilisation & extr. & Mattsson and Schjoerring, 2003 \\
\hline semi-natural & Lolium perenne & leaves after 4 days & 188 & 33000 & 20 & $3 \mathrm{mM} \mathrm{NO}_{3}^{-}$ & extr. & Mattsson and Schjoerring, 2003 \\
\hline semi-natural & Lolium perenne & in darkness & 347 & 61000 & 20 & $6 \mathrm{mM} \mathrm{NO}_{3}^{-}$ & extr. & Mattsson and Schjoerring, 2003 \\
\hline forest & - & & 0.1 & 20 & 20 & no fertilisation & extr. & Walker et al., 2008 \\
\hline
\end{tabular}

ext.: extraction measurement technique; micromet.: micrometeorological measurement technique.

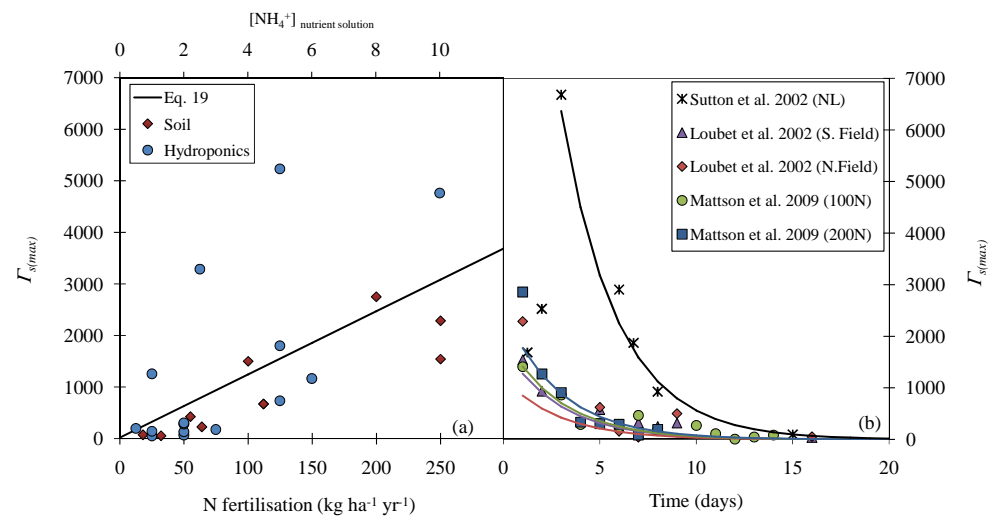

Fig. 6. (a) Compiled maximal stomatal ammonia emission potential $\left(\Gamma_{\mathrm{s}(\max )}\right)$ for managed ecosystem types (i) the first day after fertilisation (red diamonds) as a function of applied fertilisation rate (primary $\mathrm{x}$-axis) or (ii) grown in hydroponics (blue circles) as a function of [ $\left.\mathrm{NH}_{4}^{+}\right]$ concentration in the nutritive solution (secondary $\mathrm{x}$ axis). The line is the best fit linear function derived by minimisation of the least square method for the two series (hydroponics and soil). One $\mathrm{mM}$ of $\mathrm{NH}_{4}^{+}$in the nutritive solution was approximated to be equal to $22 \mathrm{~kg} \mathrm{~N}^{-1}$. (b) Dynamics of $\Gamma_{\mathrm{s}}$ in the days following $\mathrm{N}$ fertiliser application (symbols) and adjusted functions (curved lines) according to Eq. (20).

after slurry or fertiliser application. Very few measurements exist for ground layer $\mathrm{NH}_{3}$ emissions. Most of the existing data from flux measurements are for the whole canopy and therefore do not differentiate between ground layer emissions, canopy emissions and $\mathrm{NH}_{3}$ cycling within the canopy. Nemitz et al. (2000a) estimate values of $\Gamma_{\mathrm{g}}$ for oilseed rape litter based on within-canopy $\mathrm{NH}_{3}$ gradient measurements to range between 3000 and 13000 . David et al. (2009) measured much larger values based on chamber measurements in the field for an uncut grassland (140 000) and a cut grassland (260 000). Furthermore, David et al. (2009) report bare soil to have large $\Gamma_{\mathrm{g}}(50000-100000)$ in field conditions and a study above the Mojave desert reported relatively high emis- sions above a bare natural desert soil without fertiliser application (McCalley and Sparks, 2008).

Milford et al. (2001b) estimated values for $\Gamma_{\mathrm{s}}$ and $\Gamma_{\mathrm{g}}$ from flux measurements. They fitted a bi-directional model to measured night time fluxes to estimate $\Gamma_{\mathrm{g}}$, while measured day time fluxes are used to estimate values of $\Gamma_{\mathrm{s}}$.

Ground-layer emissions after slurry spreading are usually very high and reflect emission from the slurry itself (e.g. Génermont and Cellier, 1997; Flechard et al., 2010). $\Gamma_{\mathrm{g}}$ in the case of slurry can be calculated as the ratio of total ammoniacal nitrogen (TAN) content to $\mathrm{H}^{+}$content of the slurry.

Table 5 shows $\Gamma_{\mathrm{g}}$ values calculated from TAN and $\mathrm{pH}$ values given by Provolo and Martinez-Suller (2007) for 
Table 5. Mean and standard deviation of total ammoniacal nitrogen (TAN) content and pH of different slurry types from Provolo and Martinez-Suller (2007) and calculated $\Gamma_{\mathrm{g}}$ values.

\begin{tabular}{llllll}
\hline Animal type & \multicolumn{2}{c}{ Pigs } & \multicolumn{2}{c}{ Cattle } \\
\cline { 2 - 6 } & Finisher & Farrowing sows & Integrated farrow-to-finish & Dairy cows & Calves \\
\hline $\mathrm{pH}$ & $7.41 \pm 0.33$ & $7.46 \pm 0.5$ & $7.55 \pm 0.47$ & $7.34 \pm 0.42$ & $7.28 \pm 0.33$ \\
$\mathrm{TAN}\left(\mathrm{kg} \mathrm{N} \mathrm{m}^{-3}\right)$ & $2.03 \pm 0.8$ & $1.76 \pm 0.94$ & $1.61 \pm 0.66$ & $1.12 \pm 0.59$ & $1.62 \pm 0.4$ \\
$\Gamma_{\mathrm{g}}\left(\mathrm{NH}_{4}^{+} / \mathrm{H}^{+}\right)$ & $3727074 \pm 3140234$ & $3625640 \pm 6123501$ & $4080354 \pm 4936463$ & $1750209 \pm 2425068$ & $2204890 \pm 1163944$ \\
\hline
\end{tabular}

different slurry types. This derived $\Gamma_{\mathrm{g}}$ is within the range measured for the canopy $\Gamma_{\mathrm{c}}$ by Flechard et al. (2010) following six events of slurry spreading.

Ground layer emissions after mineral fertiliser application depend on the type and quantity of fertiliser applied, but also on soil properties as reflected by its $\mathrm{pH}$ buffering and water holding capacities. Concerning $\mathrm{pH}$, Harrison and Webb (2001) conclude that for urea, hydrolysis greatly increases $\mathrm{pH}$ of the soil and is therefore relatively unaffected by the soil $\mathrm{pH}$ itself. For other fertilisers, such as ammonium sulphate (AS) or di-ammonium phosphate (DAP), which increase dissolution of calcium carbonate, solution $\mathrm{pH}$ will be greater on calcareous soils. For ammonium nitrate (AN), which form readily-soluble salts with calcium, solution is unaffected by soil $\mathrm{pH}$.

\subsection{Interactions between $\Gamma_{\mathrm{s}}$ and grazing}

Concerning grazing, $\Gamma_{\mathrm{s}}$ is expected to depend on the amount of grass eaten and excreted on the field, which is related to the number of animals (in terms of livestock units) present on the field; however, few data are available in a form suitable to calculate $\Gamma$ values. Although the impact of grazing also depends on whether animals are fed solely on grass within the field or whether the animals are also fed concentrates and other forage on site or in the stable, the major impact on $\mathrm{NH}_{3}$ emissions originates from the remobilisation of plant $\mathrm{N}$ into urine and dung. During recent measurements over grazed pasture in the UK, $\Gamma_{\mathrm{s}}$ values dropped from 4000 when there were around 6.5 sheep ha ${ }^{-1}\left(\sim 1 \mathrm{LU} \mathrm{ha}^{-1}\right)$ to around 100 two weeks after the sheep were moved (Fowler et al., 2007). Milford (2004) also estimated a $\Gamma_{\mathrm{s}}$ value of 4000 for a grazed pasture with a density of 200 sheep ha $^{-1}\left(\sim 30 \mathrm{LU} \mathrm{ha}^{-1}\right)$ and the same value was confirmed during more recent measurements at the same site (Fowler et al., 2007).

\section{Proposed model and parameterisation}

Resistance models are appropriate to be integrated in chemistry and transport models as they incorporate the key elements of process understanding while being efficient in cal- culation. The key issues to which these model parameterisations should respond are the following:

- Capture dynamics of $\mathrm{NH}_{3}$ exchange with key variables ( $\mathrm{N}$ input, temperature, etc.).

- Rely on variables or outputs of chemistry and transport models (EMEP, UKCA, etc.).

- Allow response to global change variables (temperature, land use, atmospheric composition, etc.).

- Be easily implemented in global scale models.

The three types of resistance models (single layer, two-layer and multi-layer) (Nemitz et al., 2000b) previously described can theoretically all be integrated in chemistry and transport models. However, the multi-layer resistance model adds much complexity in parameterisation and calculation. The two-layer model for $\mathrm{NH}_{3}$ exchange has the advantage of capturing the soil and litter emissions. These emissions can be particularly important after fertilisation for grassland and arable ecosystems, after cutting for grassland and in case of a crop that has senescent leaves during its maturation like oilseed rape (Nemitz et al., 2000a; Sutton et al., 2009a). It can be argued however that in case of a single layer model scheme, the value of $\Gamma_{\mathrm{s}}$ attributed to a managed ecosystem after fertilisation or cutting is not a stomatal $\Gamma_{\mathrm{s}}$ but a canopy $\Gamma_{\mathrm{c}}$. Thus the $\Gamma$ value used in single layer models integrates emissions from the litter and or soil and subsequent recapture by the above canopy.

We recommend using a two-layer model since it better captures the dynamics of $\mathrm{NH}_{3}$ exchange in the case of managed ecosystems. The bottom layer of the model can be switched off for non-managed ecosystems (values of $\Gamma_{\mathrm{g}}$ are small and uncertain) by setting the in-canopy resistance $\left(R_{\mathrm{g}}\right)$ to infinity.

Based on the preceding review and data compilation, we here propose parameterisations for a bi-directional $\mathrm{NH}_{3}$ exchange scheme applying the two-layer steady state model of Nemitz et al. (2001): $\Gamma_{\mathrm{s}}, \Gamma_{\mathrm{g}}$, and $R_{\mathrm{w}}$. For completeness, we first describe the approaches for the atmospheric and canopy scale turbulent and boundary layer resistances. 


\subsection{Summary of overall concept of the two layer model}

The two-layer $\mathrm{NH}_{3}$ exchange model as described by Nemitz et al. (2001) contains bi-directional exchange with the leaf stomata, deposition to the leaf cuticle and a ground emission potential (Fig. 1b).

The total flux of ammonia $\left(F_{\mathrm{t}}\right)$ is calculated according to the following equation:

$F_{\mathrm{t}}=-\frac{\chi_{\mathrm{a}}-\chi_{(z 0)}}{R_{\mathrm{a}}}$

where $\chi_{\mathrm{a}}$ is the air ammonia concentration, $\chi_{z 0}$ is the concentration at height $d+z_{0}$ and $R_{\mathrm{a}}$ is the aerodynamic resis- tance between the air and $d+z_{0}$ that describes the vertical turbulent diffusive transport through the atmosphere between a reference height $(z)$ and displacement height $\left(d+z_{0}\right)$, which, for a closed canopy, usually equals about 0.63 times the canopy height $\left(h_{\mathrm{c}}\right)$ (Monteith, 1973).

$\chi_{(z o)}$ is calculated from the canopy ammonia concentration $\chi_{\mathrm{c}}$ which is the resultant of the stomatal flux $\left(F_{\mathrm{s}}\right)$, cuticular flux $\left(F_{\mathrm{w}}\right)$ and ground layer flux $\left(F_{\mathrm{g}}\right)$ (for more details refer to Nemitz et al., 2001). The equations for $\chi_{(z o)}$ and $\chi_{\mathrm{c}}$ are as follows:

$\chi(z 0)=\frac{\chi_{\mathrm{a}} \times R_{\mathrm{a}}^{-1}+\chi_{\mathrm{g}} \times R_{\mathrm{g}}^{-1}+\chi_{\mathrm{c}} \times R_{\mathrm{b}}^{-1}}{R_{\mathrm{a}}^{-1}+R_{\mathrm{g}}^{-1}+R_{\mathrm{b}}^{-1}}$

$\chi(c)=\frac{\chi_{\mathrm{a}} \times\left(R_{\mathrm{a}} \times R_{\mathrm{b}}\right)^{-1}+\chi_{\mathrm{s}} \times\left[\left(R_{\mathrm{a}} \times R_{\mathrm{s}}\right)^{-1}+\left(R_{\mathrm{b}} \times R_{\mathrm{s}}\right)^{-1}+\left(R_{\mathrm{g}} \times R_{\mathrm{s}}\right)^{-1}\right]+\chi_{\mathrm{g}} \times\left(R_{\mathrm{b}} \times R_{\mathrm{g}}\right)^{-1}}{\left(R_{\mathrm{a}} \times R_{\mathrm{b}}\right)^{-1}+\left(R_{\mathrm{a}} \times R_{\mathrm{S}}\right)^{-1}+\left(R_{\mathrm{a}} \times R_{\mathrm{W}}\right)^{-1}+\left(R_{\mathrm{b}} \times R_{\mathrm{g}}\right)^{-1}+\left(R_{\mathrm{b}} \times R_{\mathrm{S}}\right)^{-1}+\left(R_{\mathrm{b}} \times R_{\mathrm{W}}\right)^{-1}+\left(R_{\mathrm{g}} \times R_{\mathrm{S}}\right)^{-1}+\left(R_{\mathrm{g}} \times R_{\mathrm{W}}\right)^{-1}}$

where $R_{\mathrm{b}}, R_{\mathrm{s}}, R_{\mathrm{g}}$ and $R_{\mathrm{W}}$ are the quasi laminar boundary layer, stomatal, canopy and cuticular resistances respectively and $\chi_{\mathrm{s}}$ and $\chi_{\mathrm{g}}$ are the stomatal and ground layer compensation points, respectively.

\subsection{Parameterisation of atmospheric and boundary layer resistances}

The total resistance to exchange between a reference height and the canopy is the sum of the aerodynamic resistance $\left(R_{\mathrm{a}}\right)$ and the quasi laminar boundary layer resistance $\left(R_{\mathrm{b}}\right)$. These resistances are usually parameterised through meteorological parameters (wind speed: $u$, friction velocity: $u_{*}$, surface roughness length: $z_{o}$, and Obukhov stability length: $L$ ) (Monin and Obukhov, 1954; Sutton et al., 1993a; Högström, 1996). The boundary layer resistance $\left(R_{\mathrm{b}}\right)$ accounts for the diffusion through the quasi-laminar boundary layer at the surface of the vegetation. $R_{\mathrm{a}}$ and $R_{\mathrm{b}}$ are usually calculated in chemistry and transport models from easily measurable meteorological parameters (e.g. $R_{\mathrm{a}}$ : Garland, 1977; Monteith and Unsworth, 1990; $R_{\mathrm{b}}$ : Jensen and Hummelshøj, 1995, 1997). The commonly used equations are given below:

$R_{\mathrm{a}(\mathrm{z})}=\frac{u_{(z-d)}}{u_{*}^{2}}-\frac{\psi_{\mathrm{H}} \times\left(\frac{z-d}{L}\right)-\psi_{\mathrm{M}} \times\left(\frac{z-d}{L}\right)}{k \times u_{*}}$

$R_{\mathrm{b}}=\frac{v}{D_{\mathrm{NH}_{3}}} \times\left[\frac{c}{(\mathrm{LAI})^{2}} \times\left(\frac{l \times u_{*}}{v}\right)\right]^{1 / 3}$

where $u$ is the windspeed, $u_{*}$ is the friction velocity, $L$ is the Obukhov length, $\psi_{\mathrm{H}}$ and $\psi_{\mathrm{M}}$ are the integrated stability functions for entrained scalars and momentum respectively, $v$ is the kinematic viscosity of air $\left(\sim 1.56 \times 10^{-5} \mathrm{~m}^{2} \mathrm{~s}^{-1}\right.$ at $\left.25^{\circ} \mathrm{C}\right), D_{\mathrm{NH}_{3}}$ is the molecular diffusivity of $\mathrm{NH}_{3}$ in air $\left(\sim 2.32 \times 10^{-5} \mathrm{~m}^{2} \mathrm{~s}^{-1}\right.$ at $25^{\circ} \mathrm{C}$, Massman, 1998), $c$ is an empirical constant of order one, $k$ the von Karman constant
( $k=0.41)$, and $l$ is the length scale over which the viscous sub-layers are permitted, which is a typical leaf width. Leaf area index values for different ecosystem types and canopy heights are usually calculated or tabulated in chemistry and transport models. Simpson et al. (2003) propose a variation of LAI as well as $h_{\mathrm{c}}$ between a minimal and maximal value for different growth periods.

\subsection{Parameterisation of the in-canopy resistance}

The in-canopy transport resistance to the ground $\left(R_{\mathrm{g}}\right)$ is the sum of the aerodynamic resistance within the canopy $\left(R_{\mathrm{ac}}\right)$ and the soil boundary layer resistance $\left(R_{\mathrm{bg}}\right)$. In general, the in-canopy resistance is defined as a turbulent transport resistance and is therefore modelled as the integral of the inverse of the eddy diffusivity $\left(K_{\mathrm{H}}\right)$ between the ground surface and the roughness height $\left(d+z_{o}\right)$. $K_{\mathrm{H}}$ can be deduced according to Raupach et al. (1989) and depends on the standard deviation of the wind component $\left(\sigma_{\mathrm{w}}\right), u_{*}$ and the canopy height $\left(h_{\mathrm{c}}\right)$. Shuttleworth and Wallace $(1985)$ defined $R_{\mathrm{ac}}$ via an exponentially decaying function of $\sigma_{\mathrm{w}}$, while Wesely (1989) specified a constant in-canopy aerodynamic resistance for forest canopies and Erisman et al. (1994) suggested a formula dependent on canopy height and $u_{*}$. By contrast, Zhang et al. (2003) calculated $R_{\text {ac }}$ as a function of $u_{*}$, LAI, and the vegetation specific minimum in-canopy aerodynamic resistance. $R_{\text {bg }}$ is not explicitly considered in all studies.

Nemitz et al. (2000b) suggested using the following equation where $R_{\mathrm{ac}}$ is inversely proportional to $u_{*}$ :

$$
R_{\mathrm{ac}(d+z 0)}=\propto_{(d+z 0)} \times u_{*}^{-1}
$$


$z_{0}$ is the vegetation roughness and is usually equal to 0.13 times vegetation height $\left(h_{\mathrm{c}}\right)$, whereas $\alpha$ can be derived from Shuttleworth and Wallace (1985) as:

$$
\propto_{(d+z 0)}=\frac{1}{k} \times \frac{h_{\mathrm{c}}}{n\left(h_{\mathrm{c}}-d\right)} \times\left(e^{n}-e^{\left(n \times\left(1-\frac{d+z 0}{h_{\mathrm{c}}}\right)\right)}\right)
$$

where $n$ is the exponential decay constant (Monteith, 1973). Lafleur and Rouse (1990) suggest to calculate $n$ according to the following equation:

$n=y \times(\mathrm{LAI})^{x}$

where $y=2.6$ and $x=0.36$. The minimal value of $n$ is to be set to 1.87 and the maximal value to 3.62 .

As for the ground boundary layer resistance $\left(R_{\mathrm{bg}}\right), \mathrm{Ne}-$ mitz et al. (2001) suggest to calculate it according to Schuepp (1977):

$R_{\mathrm{bg}}=\frac{v / D_{\mathrm{NH}_{3}}-\ln \left(\delta_{0} / z_{1}\right)}{k u_{* g}}$

where $\delta_{0}$ is the distance above ground where the eddy diffusivity is equal in magnitude to the molecular diffusivity of $\mathrm{NH}_{3}, z_{1}$ is the upper height of the logarithmic profile that forms above the ground and $u_{* g}$ is the friction velocity at ground level. If at height $z_{1}$, we consider that the vertical wind speed $\left(u_{(y)}\right)$, the eddy diffusivity $\left(K_{\mathrm{H}}\right)$, and the slope of $K_{\mathrm{H}}$ are equal between the exponential and the logarithmic profiles above and below $z_{1}$ respectively, then we can derive an expression for $u_{* g}$ and $z_{1}$ as a function canopy height $\left(h_{\mathrm{c}}\right)$, the exponential decay constant $(n)$ and the eddy diffusivity $\left(K_{\mathrm{H}}\right)$. In case LAI and $h_{\mathrm{c}}$ values are not provided by the model calculations, Table 6 summarises proposed default parameter estimates according to ecosystem type and season to be used in Eqs. (13), (14), (15) and (16).

\subsection{Parameterisation of $\chi_{\mathrm{s}}$ for non-agricultural ecosystems}

We propose to use Eq. (8) to parameterise $\Gamma_{\mathrm{s}}$ for both forest and short semi-natural ecosystems because there does not appear to be a significant difference in the response of $\Gamma_{\mathrm{s}}$ to the $N_{\text {dep }}$ between those two ecosystem types. The fitted equation represents rather well the data with an adjusted $R^{2}$ value of 0.75 . There is however variability in $\Gamma_{\mathrm{s}}$ which is not explained by $N_{\text {dep }}$ especially for low $\Gamma_{\mathrm{s}}$ values. This is likely to reflect uncertainties in our $N_{\text {dep }}$ estimate (for example $\mathrm{N}$ fixation and organic $\mathrm{N}$ deposition are not considered as an $\mathrm{N}$ source), but also reflects differences between species. For example, Mattsson et al. (2009b) found that values of $\Gamma_{\mathrm{s}}$ ranged from 25 to 700 between grass species growing within the same sward (and thus receiving the same $\mathrm{N}$ deposition). These uncertainties reflect the limitations of our current understanding in the controls of $\Gamma_{\mathrm{s}}$.

\subsection{Parameterisation of $\chi_{\mathrm{s}}$ and $\chi_{\mathrm{g}}$ for agricultural ecosystems}

In the case of managed ecosystems, $\Gamma_{\mathrm{s}}$ and $\Gamma_{\mathrm{g}}$ are reported to depend on the $\mathrm{N}$ input via fertilisation or grazing. Time series measurements of $\Gamma$ usually show a peak after fertilisation events (e.g. Loubet et al., 2002; Mattsson et al., 2009a). This high $\Gamma$ after fertilisation or during grazing usually decreases when the cattle are removed from the field or in the week following fertiliser application. These high measurements reflect ground (soil/fertiliser and or litter) emissions as well as stomatal exchange. We propose a parameterisation that distinguishes background $\Gamma_{\mathrm{s}}$ values (i.e. before fertilisation) and values of $\Gamma_{\mathrm{s}}$ and $\Gamma_{\mathrm{g}}$ after management events such as fertiliser application.

In our parameterisation we only use the ground layer $\left(\Gamma_{\mathrm{g}}\right)$ for the periods following management events. This is done for two main reasons: (i) very few data are available on ground layer emissions from background, (ii) ground layer emissions are expected to be small and recaptured by the overlying canopy, except following management events and in the case of senescing arable canopies, where bottom layers emit considerable amounts of $\mathrm{NH}_{3}$ (Nemitz et al., 2000a) and (iii) most of the compensation point measurements for this type of ecosystems are measurements which often do not differentiate clearly between $\Gamma_{\mathrm{s}}$ and $\Gamma_{\mathrm{g}}$ and therefore reflect in some of the cases a measurement of $\Gamma_{\mathrm{c}}$. Therefore proposing a big leaf model in those cases might be a way to limit the uncertainty both related to the quality of the measurements and the lack of data. A special case to be considered is managed bare soil (tilled land outside the growing season). In this case we might assume that $\Gamma_{\mathrm{g}}$ is different from zero since some plant litter remains on the soil surface. Nemitz et al. (2001) estimated a $\Gamma_{\mathrm{g}}$ over a wheat stubble equal to 630 . We therefore suggest using $\Gamma_{\mathrm{g}}=500$ for managed tilled land outside the vegetation season.

- Background $\Gamma_{\mathrm{s}}$

Agricultural ecosystems receive $\mathrm{N}$ in two major forms: fertiliser application and $\mathrm{N}$ input through atmospheric deposition. We propose to use Eq. (9) to estimate $\Gamma_{\mathrm{s}}$ from total $\mathrm{N}$ input to the ecosystem (fertiliser application and $N_{\text {dep }}$ ) as a parameterisation for managed background $\Gamma_{\mathrm{s}}$.

\section{- Temporal dynamics in $\Gamma_{\mathrm{s}}$ after fertilisation}

In the days following fertiliser application, there is usually a peak in $\Gamma$ which is due to emission from the fertiliser or slurry itself but also from the plant canopy. The dependence of the maximal $\Gamma_{\mathrm{s}}$ values after fertilisation on the amount of fertiliser applied $\left(\mathrm{kg} \mathrm{N} \mathrm{ha}^{-1}\right)$ or $\left[\mathrm{NH}_{4}^{+}\right]$concentration in the nutritive solution (Fig. 6a) reveals a linear relationship which can be approximated by:

$\Gamma_{s(\max )}=12.3 \times N_{\mathrm{app}}+20.3$ 
Table 6. Parameters used for the calculation of aerodynamic and boundary layer resistances above $\left(R_{\mathrm{a}}\right.$ and $\left.R_{\mathrm{b}}\right)$ and within canopy $\left(R_{\mathrm{ac}}\right)$, respectively.

\begin{tabular}{|c|c|c|c|c|c|c|c|c|}
\hline Ecosystem type & Season & $\begin{array}{r}\text { LAI } \\
\left(\mathrm{m}^{2} \mathrm{~m}^{-2}\right)\end{array}$ & $\begin{array}{r}l \\
\text { (m) }\end{array}$ & $\begin{array}{r}h_{\mathrm{c}} \\
(\mathrm{m})\end{array}$ & $\begin{array}{r}z_{0} \\
(\mathrm{~m})\end{array}$ & $\begin{array}{r}d \\
(\mathrm{~m})\end{array}$ & $n$ & $\alpha$ \\
\hline \multirow[t]{4}{*}{ Temperate/boreal coniferous forests } & winter & 3.4 & 0.005 & 20 & 2.6 & 12.6 & 3.62 & 65.24 \\
\hline & spring & 4 & 0.005 & 20 & 2.6 & 12.6 & 3.62 & 65.24 \\
\hline & summer & 4.5 & 0.005 & 20 & 2.6 & 12.6 & 3.62 & 65.24 \\
\hline & autumn & 4 & 0.005 & 20 & 2.6 & 12.6 & 3.62 & 65.24 \\
\hline \multirow[t]{4}{*}{ Temperate/boreal deciduous forests } & winter & 3.5 & 0.05 & 20 & 2.6 & 12.6 & 3.62 & 65.24 \\
\hline & spring & 4.2 & 0.05 & 20 & 2.6 & 12.6 & 3.62 & 65.24 \\
\hline & summer & 5 & 0.05 & 20 & 2.6 & 12.6 & 3.62 & 65.24 \\
\hline & autumn & 3.9 & 0.05 & 20 & 2.6 & 12.6 & 3.62 & 65.24 \\
\hline \multirow[t]{4}{*}{ Mediterranean needleleaf forests } & winter & 3.5 & 0.005 & 15 & 1.95 & 9.45 & 3.62 & 65.24 \\
\hline & spring & 3.5 & 0.005 & 15 & 1.95 & 9.45 & 3.62 & 65.24 \\
\hline & summer & 3.5 & 0.005 & 15 & 1.95 & 9.45 & 3.62 & 65.24 \\
\hline & autumn & 3.5 & 0.005 & 15 & 1.95 & 9.45 & 3.62 & 65.24 \\
\hline \multirow[t]{4}{*}{ Mediterranean broadleaf forests } & winter & 3.5 & 0.05 & 15 & 1.95 & 9.45 & 3.62 & 65.24 \\
\hline & spring & 3.5 & 0.05 & 15 & 1.95 & 9.45 & 3.62 & 65.24 \\
\hline & summer & 3.5 & 0.05 & 15 & 1.95 & 9.45 & 3.62 & 65.24 \\
\hline & autumn & 3.5 & 0.05 & 15 & 1.95 & 9.45 & 3.62 & 65.24 \\
\hline \multirow[t]{4}{*}{ Temperate Crops } & winter & 0 & 0.02 & 0 & 0 & 0 & 1.87 & 17.78 \\
\hline & spring & 2.5 & 0.02 & 0.6 & 0.08 & 0.378 & 3.62 & 65.04 \\
\hline & summer & 3.5 & 0.02 & 1 & 0.13 & 0.63 & 3.62 & 65.24 \\
\hline & autumn & 0 & 0.02 & 0 & 0 & 0 & 1.87 & 17.78 \\
\hline \multirow[t]{4}{*}{ Mediterranean Crops } & winter & 0 & 0.03 & 2 & 0.26 & 1.26 & 1.87 & 17.78 \\
\hline & spring & 2 & 0.03 & 2 & 0.26 & 1.26 & 3.34 & 52.45 \\
\hline & summer & 3 & 0.03 & 2 & 0.26 & 1.26 & 3.62 & 65.24 \\
\hline & autumn & 0 & 0.03 & 2 & 0.26 & 1.26 & 1.87 & 17.78 \\
\hline \multirow[t]{4}{*}{ Root Crops } & winter & 0 & 0.04 & 0 & 0 & 0 & 1.87 & 17.78 \\
\hline & spring & 2.5 & 0.04 & 0.5 & 0.065 & 0.315 & 3.62 & 65.04 \\
\hline & summer & 4.2 & 0.04 & 0.5 & 0.065 & 0.315 & 3.62 & 65.24 \\
\hline & autumn & 2 & 0.04 & 0 & 0 & 0 & 3.34 & 52.45 \\
\hline \multirow[t]{4}{*}{ Seminatural/Moorland } & winter & 2 & 0.01 & 0.5 & 0.065 & 0.315 & 3.34 & 52.45 \\
\hline & spring & 3 & 0.01 & 0.5 & 0.065 & 0.315 & 3.62 & 65.24 \\
\hline & summer & 3 & 0.01 & 0.5 & 0.065 & 0.315 & 3.62 & 65.24 \\
\hline & autumn & 2 & 0.01 & 0.5 & 0.065 & 0.315 & 3.34 & 52.45 \\
\hline \multirow[t]{4}{*}{ Grassland } & winter & 2 & 0.01 & 0.3 & 0.039 & 0.189 & 3.34 & 52.45 \\
\hline & spring & 3 & 0.01 & 0.3 & 0.039 & 0.189 & 3.62 & 65.24 \\
\hline & summer & 3.5 & 0.01 & 0.3 & 0.039 & 0.189 & 3.62 & 65.24 \\
\hline & autumn & 2 & 0.01 & 0.3 & 0.039 & 0.189 & 3.34 & 52.45 \\
\hline \multirow[t]{4}{*}{ Mediterranean shrub } & winter & 2.5 & 0.02 & 2 & 0.26 & 1.26 & 3.62 & 65.04 \\
\hline & spring & 2.5 & 0.02 & 2 & 0.26 & 1.26 & 3.62 & 65.04 \\
\hline & summer & 2.5 & 0.02 & 2 & 0.26 & 1.26 & 3.62 & 65.04 \\
\hline & autumn & 2.5 & 0.02 & 2 & 0.26 & 1.26 & 3.62 & 65.04 \\
\hline Wetlands & All year & 1 & 0.01 & 0.5 & 0.065 & 0.315 & 2.60 & 30.14 \\
\hline Tundra & All year & 1 & 0.01 & 0.5 & 0.065 & 0.315 & 2.60 & 30.14 \\
\hline Desert/Bare soil & All year & 0 & 0 & 0 & - & - & - & - \\
\hline
\end{tabular}


Table 7. Soil water content $\left(\theta_{\mathrm{S}}\right.$ in $\left.\%\right)$ at field capacity and permanent wilting point according to soil type from Lambers et al. (2008).

\begin{tabular}{lccc}
\hline & sand & loam & Clay \\
\hline Field capacity & 10 & 20 & 40 \\
Permanent wilting point & 5 & 10 & 20 \\
\hline
\end{tabular}

This $\Gamma_{\mathrm{s}(\max )}$ reflects mineral fertiliser application. We only have one dataset where manure application was coupled with apoplast extraction measurements (Sutton et al., 2002 (NL)). We notice a similar response to mineral $\mathrm{N}$ application with respect to the peak value of $\Gamma_{\mathrm{s}}$, however, dynamics in this case is different. Organic fertiliser application should be treated with caution due to the shortage of data.

The temporal decrease in $\Gamma_{\mathrm{s}(\max )}$ after a fertilisation event can be adjusted to an exponential function as shown in Fig. 6b. The exponential equation is of the following form:

$\Gamma_{\mathrm{s}}=\Gamma_{\mathrm{s}(\max )} \times e^{(-t / \tau)}$

where $\Gamma_{\mathrm{s}(\max )}$ is from Eq. (19), $\tau$ is the e-folding time constant of the decay and is set to 2.88 days, and $t$ is the time in days. This type of parameterisation can be applied the day following fertiliser application since the peaks in $\Gamma_{\mathrm{s}}$ values are directly observed in most of the cases. We propose using Eqs. (19) and (20) to parameterise $\Gamma_{\mathrm{s}}$ dynamics after a fertilisation event.

- Temporal dynamics in $\Gamma_{\mathrm{g}}$ after fertilisation and/or grazing

We suggest using the same $\Gamma$ dynamics equation for the ground layer as for the plant layer (Eq. 20). Given that in the days following slurry spreading or fertiliser application, most of the emissions are from the slurry or fertiliser itself, we propose using $\Gamma_{\mathrm{g}(\max )}$ equal to $\Gamma_{\mathrm{g}}$ of the slurry or fertiliser used. As for $\tau$ we propose to use a value of 2.88 days similar to the value used for $\Gamma_{\mathrm{s}}$ parameterisation.

In the case of slurry, $\Gamma_{\mathrm{g}(\max )}$ is calculated from TAN content and $\mathrm{pH}$ of the slurry. Typical values for different organic fertiliser types are given in Table 5.

For mineral fertiliser application, we propose to estimate a $\Gamma$ value for the fertiliser in the top $5 \mathrm{~cm}$ of the ground layer. If we suppose that the applied $\mathrm{N}$ fertiliser is dissolved in the soil water content in the top $5 \mathrm{~cm}$ of the ground layer then we can approximate $\Gamma_{\mathrm{g}(\max )}$ by the following equation:

$\Gamma_{\mathrm{g}(\max )}=\frac{N_{\mathrm{app}} / \theta_{\mathrm{s}} \times M_{\mathrm{N}} \times l_{\mathrm{s}} \times h_{\mathrm{m}}}{10^{-\mathrm{pH}}}$ where $N_{\text {app }}$ is the $\mathrm{N}$ content of the applied fertiliser in $\mathrm{kg}-\mathrm{N} \mathrm{ha}{ }^{-1}, \theta_{\mathrm{s}}$ is the soil percentage water content, $M_{\mathrm{N}}$ is the molar mass of nitrogen $\left(14 \mathrm{~g} \mathrm{~mol}^{-1}\right), l_{\mathrm{S}}$ is the soil layer where fertiliser is applied (typically $0.05 \mathrm{~m}$ ), $h_{\mathrm{m}}$ is to convert hectares to $\mathrm{m}(=10000 \mathrm{~m})$ and $\mathrm{pH}$ is the $\mathrm{pH}$ of the soil solution after fertiliser application. Soil water content depends on meteorological conditions as well as soil type. Rough values for $\theta_{\mathrm{s}}$ are given in Table 7 for different soil types. Concerning $\mathrm{pH}$, we propose to use a $\mathrm{pH}$ value of 7.5 for urea based fertilisers and AS or DAP based fertilisers in calcareous soils and a $\mathrm{pH}$ value of 7 for AS and DAP fertilisers in acidic soils and AN fertilisers. In the case of significant rainfall, nitrate $\mathrm{N}$ might be lost in leaching; this can also trigger soil microbiology therefore altering $\Gamma_{\mathrm{g}}$. Very few measurements exist under these conditions. Equation (21) is a rough approximation of fertiliser emissions and should be better evaluated and tested.

For grazing, one could assume that it depends on the intensity or the number of live units of cattle per hectare. The few data available show similar $\Gamma$ values for fields extensively or intensively grazed (Milford, 2004; Fowler et al., 2007). We therefore propose to use a constant $\Gamma_{\mathrm{g}}$ for grazed grasslands equals to 4000 until the animals are removed from the field.

One should note, however, that usually emissions of $\mathrm{NH}_{3}$ from fertiliser application and grazing are accounted for as biogenic emissions derived from inventories in several models (EMEP, CHIMERE, etc.). Therefore when integrating the bi-directional exchange scheme described here corrections to avoid double counting are necessary.

\subsection{Proposed parameterisation for $\boldsymbol{R}_{\mathrm{W}}$}

The cuticular resistance $\left(R_{\mathrm{W}}\right)$ clearly depends on air relative humidity as expressed in Eq. (3). From Fig. 2 it is difficult to see a pattern in the data as a whole. However, there is a relationship between $R_{\mathrm{w}(\mathrm{corr})}$ at $95 \% \mathrm{RH}$ and AR, the molar ratio of total acid/ $\mathrm{NH}_{3}$ in the atmosphere, as shown in Fig. 7. The functions per ecosystem type of $R_{\mathrm{w}(\mathrm{corr})}$ at $95 \% \mathrm{RH}$ versus AR are also shown, which is an expansion of the analysis by Nemitz et al. (2001). The data as divided per ecosystem seem rather scattered. We therefore propose to use the power fit (Eq. 22 below) for all ecosystems as a parameterisation of 


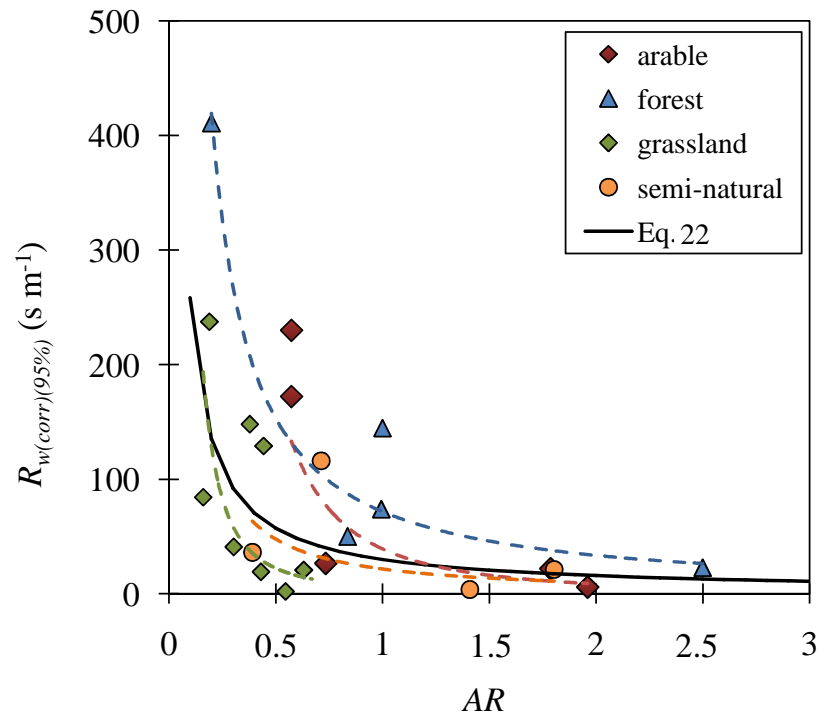

Fig. 7. Cuticular resistance at $95 \%$ relative humidity $\left(R_{\mathrm{w}(\mathrm{corr})(95 \%)}\right)$ as a function of the ratio of total

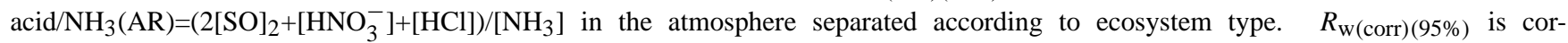
rected for LAI and temperature. Dotted lines represent the corresponding fitted power curves to the data by ecosystem type. The solid line represents the fitted power curve to all ecosystem types.

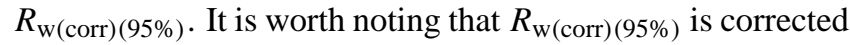
for LAI and temperature according to Eq. (4).

$$
R_{\mathrm{W}(\operatorname{corr})(95 \%)}=29.9 \times(\mathrm{AR})^{-1}
$$

If we consider that the relation between $\mathrm{RH}$ and $R_{\mathrm{w} \text { (corr) }}$ is linear for relative humidity values between 95 and $100 \%$ then:

$$
R_{\mathrm{w}(\mathrm{corr})(\min )}=R_{\mathrm{W}(\operatorname{corr})(100 \%)}=31.5 \times(\mathrm{AR})^{-1}
$$

Thus combining Eq. (3) and Eq. (23) above we obtain the following equation which we propose as a parameterisation for $R_{\mathrm{W}}$ :

$R_{\mathrm{w}(\mathrm{corr})}=31.5 \times(\mathrm{AR})^{-1} \times e^{a(100-\mathrm{RH})}$

Concerning the parameter $a$, deriving a generalised parameterisation for it seems much more challenging because its biological or physical significance is not fully understood. We could not find any relation between values of the parameter $a$ for the compiled data and reported dependencies of $R_{\mathrm{W}}$ such as aerosol burden or leaf wetting potential. We therefore suggest using the average values per ecosystem type of the parameter $a$ for the compiled $R_{\mathrm{W}}$ data.

- Forest: $a=0.0318 \pm 0.0179$ (st. dev.)

- Grassland: $a=0.176 \pm 0.126$ (st. dev.)

- Short semi-natural: $a=0.120 \pm 0.107$ (st. dev.)

- Arable: $a=0.148 \pm 0.113$ (st. dev.)

\section{Limitations of the approach}

The parameterisation of the bi-directional exchange model presented here provides a basis for integrating ammonia exchange processes into large scale chemical transport and earth system models. One of its major advantages as compared to the parameterisation proposed by Zhang et al. (2010) is the mechanistic linkage between $\Gamma$ and atmospheric $\mathrm{N}$ deposition but also between $\Gamma$ and agricultural practices. This approach therefore allows ecosystems to dynamically respond to changes in emissions and deposition patterns but also to land management events. It has, however, several limitations.

- Uncertainties. The parameterisation derived here relies on measurements of $\Gamma_{\mathrm{s}}$ and atmospheric $\mathrm{N}$ deposition, both of which are subject to uncertainties. There is no absolute reference method for estimating $\Gamma_{\mathrm{s}}$, while $\mathrm{N}$ deposition rates were extracted from sources of varying quality. As for $R_{\mathrm{W}}$, as stated earlier, we do not have a direct measurement technique and can only derive values for it by making certain assumptions. Furthermore, the relationships established between different variables are far from perfectly correlated. This is especially true for example for the maximum $\Gamma_{\mathrm{s}}$ values as a function of mineral $\mathrm{N}$ fertiliser application (Fig. 6a). These particular data are very scattered, probably due to the different conditions specific to each experiment and the different types of fertiliser applied (nitrate, ammonium or ammonium nitrate). There is currently a lack of measurements for $\Gamma_{\mathrm{s}}$ with organic fertiliser (manure, slurry and 
Table 8. Summary of the proposed parameterisation of a two-layer $\mathrm{NH}_{3}$ bi-directional exchange model.

\begin{tabular}{|c|c|c|c|c|c|c|}
\hline & & & \multicolumn{2}{|c|}{$\Gamma$} & \multicolumn{2}{|l|}{$R_{w}$} \\
\hline & & & $\Gamma_{s}$ & $\Gamma_{g}$ & $R_{w \min }$ & $a$ \\
\hline \multicolumn{3}{|c|}{ Un-managed } & $\Gamma_{S}=246+(0.0041) \times\left(N_{i n}\right)^{3.56}$ & $\mathrm{~N} / \mathrm{A}\left(R_{g}=\infty\right)$ & \multirow{6}{*}{$R_{w}=R_{w(\min )} \times e^{a \times(100-R H)}$} & \multirow{3}{*}{$\begin{array}{l}\cdot \text { Forest: } \\
0.0318 \pm 0.0179 \\
\text { • Semi-natural } \\
0.120 \pm 0.107\end{array}$} \\
\hline \multirow{5}{*}{$\begin{array}{l}\text { D } \\
\stackrel{\mathscr{D}}{\mathscr{T}} \\
\stackrel{\mathbb{T}}{\Sigma} \\
\stackrel{\mathbb{\pi}}{\Sigma}\end{array}$} & \multirow{2}{*}{ Background } & $\begin{array}{l}\text { Without } \\
\text { vegetation }\end{array}$ & $\mathrm{N} / \mathrm{A}\left(R_{s}\right.$ and $\left.R_{w}=\infty\right)$ & $\Gamma_{g}=500$ & & \\
\hline & & $\begin{array}{l}\text { With } \\
\text { vegetation }\end{array}$ & $\Gamma_{s}=66.4+(0.0853) \times\left(N_{i n}\right)^{1.59}$ & $\mathrm{~N} / \mathrm{A}\left(R_{g}=\infty\right)$ & & \\
\hline & \multirow{3}{*}{$\begin{array}{l}\text { Management } \\
\text { events }\end{array}$} & $\begin{array}{l}\text { Mineral } \\
\text { fertilisation }\end{array}$ & \multirow{3}{*}{$\begin{array}{c}\Gamma_{s(\max )}=12.3 \times N_{a p p .}+20.3 \\
\tau=2.88 \text { days }\end{array}$} & $\begin{array}{c}\Gamma_{\mathrm{g}}=\Gamma_{\mathrm{g}_{(\max )}} \times e^{(-t / \tau)} \\
\Gamma_{g(\max )}=\frac{N_{a p p} / \theta_{s} \times M_{N} \times l_{s} \times h_{m}}{10^{-p H}} \\
\tau=2.88 \text { days }\end{array}$ & & \multirow[t]{3}{*}{$\begin{array}{l}\cdot \text { Arable: } \\
0.148 \pm 0.113 \\
\\
\text { - Grassland } \\
0.176 \pm 0.126\end{array}$} \\
\hline & & $\begin{array}{l}\text { Organic } \\
\text { fertilisation }\end{array}$ & & $\begin{array}{c}\Gamma_{\mathrm{g}}=\Gamma_{\mathrm{g}_{(\max )}} \times e^{(-t / \tau)} \\
\Gamma_{g(\max )}=\frac{T A N_{\text {slurry }}}{10^{-p H \text { slurry }}} \\
\tau=2.88 \text { days }\end{array}$ & & \\
\hline & & Grazing & & $\begin{array}{c}\Gamma_{\mathrm{g}}=\Gamma_{\mathrm{g}(\max )} \times e^{(-t / \tau)} \\
\Gamma_{\mathrm{g}(\max )}=4000 \\
\tau=2.88 \text { days (after cattle are } \\
\text { removed from field) }\end{array}$ & & \\
\hline
\end{tabular}

$\Gamma$ is unitless; $t$ and $\tau$ are in days; $R_{\mathrm{W}(\text { corr })}$ is in $\mathrm{s} \mathrm{m}^{-1}$;

$N_{\text {in }}$ and $N_{\text {app }}$ are the total $\mathrm{N}$ input to the ecosystem $\left(N_{\text {app }}+\mathrm{N}\right.$ deposition $)$ and $\mathrm{N}$ applied as fertiliser respectively in $\mathrm{kg} \mathrm{ha}^{-1} \mathrm{yr}^{-1}$.

urea) application events. Nevertheless, the parameterisation proposed here provides a first attempt to move from a static offline emission inventory approach to the dynamic modelling of emissions, at least for fertilised land. This simple approach takes into account the effect of temperature on the emission and, to some extent, precipitation, but leaves scope for future refinement. There is also a significant scatter in $R_{\mathrm{w}(\min )}$ as a function of the ratio of total atmospheric acid to $\mathrm{NH}_{3}$ concentrations for arable and short semi-natural ecosystems.

- Applicability. The stomatal ammonia compensation point is not only driven by $\mathrm{N}$ input to the ecosystem, it is a strongly regulated process that depends on plant metabolism and environmental conditions (Riedo et al., 2002; Massad et al., 2008). The parameterisation proposed here would therefore not capture the dynamics of $\Gamma_{\mathrm{s}}$ at a field or plant scale. For example, Mattsson et al. (2009b) observed high variability of $\Gamma_{\mathrm{s}}$ between different grass species in the same sward (and thus subjected to the same $N_{\text {dep }}$ ). It should also be noted that $R_{\mathrm{W}}$ is set as a function of $\mathrm{RH}, \mathrm{NH}_{3}$ and total acid concentrations measured at a reference height above the canopy, when in fact, $R_{\mathrm{w}}$ will more closely respond to the values at the leaf surfaces. This is a necessary simplification, since surface concentrations are highly dependent on the fluxes, so that accounting for this would make the calculations much more complex. Finally, the data available for $\Gamma_{\mathrm{S}}$ as well as $R_{\mathrm{W}}$ values are limited mainly to Northern European ecosystems. Very few data are available covering other geographical regions (especially tropical and subtropical climates). While the parameterisations are expected to be reasonably robust in very cold climates (with freezing conditions increasing $R_{\mathrm{W}}$ ), the uncertainties are much larger for application to warmer climates, for example where soil and litter decomposition processes may have a larger effect on net ammonia fluxes. In addition, $\mathrm{N}$ fixation, not quantified in most chemistry and transport models becomes a large fraction of the $\mathrm{N}$ input at many tropical sites.

- Scaling. The parameterisation proposed here requires land use data as well as agricultural practice data to be integrated at sub-grid level in large scale models. This limits the model to situations where accurate agricultural practice data are accessible, while sub-grid resolution should be defined in accordance with land use data available and type of model used. Another important limitation is the availability of $\mathrm{NH}_{3}$ concentrations and acid ratios at sub-grid level (by landuse type). $\mathrm{NH}_{3}$ concentration for example over an agricultural area will be much greater than over a semi-natural area. 
- Circularity. There remains the issue of circularity in solving the model, since the parameterisation proposed requires the use of atmospheric $\mathrm{N}$ deposition and $\mathrm{NH}_{3}$ concentration data as a basis to infer $\mathrm{NH}_{3}$ fluxes. This issue can be addressed by spinning up the model with the same year several times, so that it converges to a constant $\mathrm{N}$ deposition value. Once an initial model time series is available, $\mathrm{N}$ deposition rates data from previous years are appropriate to use in the parameterisation of $\Gamma_{\mathrm{s}}$.

\section{Conclusions}

A complete parameterisation for estimating bi-directional exchange of $\mathrm{NH}_{3}$ suitable for atmospheric chemistry and transport models is presented. The parameterisation includes newly developed specifications for the cuticular resistance and the stomatal compensation point. A summary is presented in Table 8. Currently, most regional models only treat dry deposition of ammonia, and do not address bidirectional exchange. Incorporating this effect can be expected to improve the estimation of $\mathrm{NH}_{3}$ atmospheric concentrations and total atmospheric $\mathrm{N}$ deposition over ecosystems. Nevertheless, there are relatively limited measurements of the key model parameters: the temperature normalized stomatal compensation point $\left(\Gamma_{\mathrm{s}}\right)$ and the resistance for deposition to plant surfaces $\left(R_{\mathrm{w}}\right)$, with most data available for temperate, European conditions. Although in the absence of other measurements, the principles of this parameterisation can be expected to apply for other climates, the uncertainties are expected to be largest in sub-tropical and tropical conditions, where background soil mineralization processes may have a larger effect on net ammonia fluxes. Future steps should include a thorough validation by integrating the parameterisation in a large scale system model and comparing the output to point measurements, previous model outputs and other simulation models. Further model developments, beyond that presented in this paper would rely heavily on the future availability of more extensive and detailed ammonia flux measurements but also on more sophisticated sub-grid treatments in chemistry and transport models.

Acknowledgements. This work was funded by the UK Natural Environment Research Council through the QUAAC project of the QUEST (Quantifying the Earth System) programme, with additional contributions from the UK Department for Environment, Food and Rural Affairs through the Acid Deposition Processes project and the Integrated Project "NitroEurope" funded by the European Commission.

Edited by: D. Simpson

\section{References}

Adams, P. J., Seinfeld, J. H., Koch, D., Mickley, L., and Jacob, D.: General circulation model assessment of direct radiative forcing by the sulfate-nitrate-ammonium-water inorganic aerosol system. J. Geophys. Res-Atmos., 106, 1097-1111, 2001.

Andersen, H. V., Hovmand, M. F., Hummelshoj, P., and Jensen, N. O.: Measurements of ammonia concentrations, fluxes and dry deposition velocities to a spruce forest 1991-1995, Atmos. Environ., 33, 1367-1383, 1999.

Bleeker, A., Sutton, M. A., Acherman, B., Alebic-Juretic, A., Aneja, V. P., Ellermann, T., Erisman, J. W., Fowler, D., Fagerli, H., Gauger, T., Harlen, K. S., Hole, L. R., Horvath, L., Mitosinkova, M., Smith, R. I., Tang, Y. S., and Pul, A.: Linking ammonia emission trends to measured concentrations and deposition of reduced nitrogen at different scales, in: Atmospheric Ammonia - Detecting emission changes and environmental impacts. Results of an expert workshop under the convention of long-range transboundary air pollution, edited by: Sutton M. A., Reis S., Baker S. M. H. , Atmospheric Ammonia - Detecting emission changes and environmental impacts. Results of an expert workshop under the convention of long-range transboundary air pollution, Springer, 123-180, 2009.

Burkhardt, J., Flechard, C. R., Gresens, F., Mattsson, M., Jongejan, P. A. C., Erisman, J. W., Weidinger, T., Meszaros, R., Nemitz, E., and Sutton, M. A.: Modelling the dynamic chemical interactions of atmospheric ammonia with leaf surface wetness in a managed grassland canopy, Biogeosciences, 6, 67-84, doi:10.5194/bg-667-2009, 2009.

Byun, D. and Schere, K. L.: Review of the Governing Equations, Computational Algorithms, and Other Components of the Models-3 Community Multiscale Air Quality (CMAQ) Modeling System, Appl. Mech. Rev., 59, 51-77, 2006.

Cooter, E. J. and Bash, J. O.: A process based ammonia emission model for agricultural soils, NADP Annual meeting and scientific symposium, October 8, 2009.

Cooter, E. J., Bash, J. O., Walker, J. T., Jones, M. R., and Robarge, W.: Estimation of $\mathrm{NH}_{3}$ bi-directional flux from managed agricultural soils, Atmos. Environ., 44, 2107-2115, 2010.

Dabney, S. M. and Bouldin, D. R.: Apparent deposition velocity and compensation point of ammonia inferred from gradient measurements above and through alfalfa. Atmos. Environ. Part A. General Topics, 24, 2655-2666, 1990.

David, M., Loubet, B., Cellier, P., Mattsson, M., Schjoerring, J. K., Nemitz, E., Roche, R., Riedo, M., and Sutton, M. A.: Ammonia sources and sinks in an intensively managed grassland canopy, Biogeosciences, 6, 1903-1915, doi:10.5194/bg-6-19032009, 2009.

Dewar, R. C.: The Ball-Berry-Leuning and Tardieu-Davies stomatal models: synthesis and extension within a spatially aggregated picture of guard cell function, Plant, Cell Environ., 25, 13831398, 2002.

Dijk, N., Leith, I. D., Pitcairn, C. E. R., and Sutton, M. A.: Soluble ammonium in plants as a bioindicator for atmospheric nitrogen deposition: refinement and testing of a practical method, in: Atmospheric Ammonia - Detecting emission changes and environmental impacts. Results of an expert workshop under the convention of long-range transboundary air pollution, edited by: Sutton, M. A., Reis, S., and Baker, S. M. H., Springer, 281-289, 2009. 
Duyzer, J.: Dry depoistion of ammonia and ammoniium aerosols over heathland, J. Geophys. Res-Atmos, 99, 18757-18763, 1994.

Erisman, J. W. and Wyers, G. P.: Continuous measurements of surface exchange of $\mathrm{SO}_{2}$ and $\mathrm{NH}_{3}$ - Implication for their possible interaction in the deposition process, Atmos. Environ. Part a-General Topics, 27, 1937-1949, 1993.

Erisman, J. W.: Evaluation of a surface resistance parametrization of sulfur-dioxide, Atmos. Environ., 28, 2583-2594, 1994.

Erisman, J. W., Vanelzakker, B. G., Mennen, M. G., Hogenkamp, J., Zwart, E., Vandenbeld, L., Romer, F. G., Bobbink, R., Heil, G., Raessen, M., Duyzer, J. H., Verhage, H., Wyers, G. P., Otjes, R. P., and Mols, J. J.: The Elspeetsche Veld experiment on surface exchange of trace gases - Summary of results, Atmos. Environ., 28, 487-496, 1994.

Erisman, J. W., Sutton, M. A., Galloway, J., Klimont, Z., and Winiwarter, W.: How a century of ammonia synthesis changed the world, Nat. Geosci., 1, 636-639, 2008.

Farquhar, G. D., Firth, P. M., Wetselaar, R., and Weir, B.: On the gaseous exchange of ammonia between leaves and the environment: determination of the ammonia compensation point, Plant Physiol., 66, 710-714, 1980.

Finlayson-Pitts, B. J. and Pitts, J. N.: Chemistry of the upper and lower atmosphere: theory, experiments, and applications, Academic Press, San Diego, CA, 969 pp., 1999.

Finnemann, J. and Schjoerring, J. K.: Translocation of $\mathrm{NH}_{4}^{+}$in oilseed rape plants in relation to glutamine synthetase isogene expression and activity, Physiol. Plantarum, 105, 469-477, 1999.

Flechard, C. R.: Turbulent exchange of ammonia above vegetation, Nottingham University, 231 pp., 1998.

Flechard, C. R. and Fowler, D.: Atmospheric ammonia at a moorland site. I: The meteorological control of ambient ammonia concentrations and the influence of local sources, Q. J. Roy Meteor. Soc., 124, 733-757, 1998.

Flechard, C. R., Fowler, D., Sutton, M. A., and Cape, J. N.: A dynamic chemical model of bi-directional ammonia exchange between semi-natural vegetation and the atmosphere, Q. J. Roy Meteor. Soc., 125, 2611-2641, 1999.

Flechard, C. R., Spirig, C., Neftel, A., and Ammann, C.: The annual ammonia budget of fertilised cut grassland - Part 2: Seasonal variations and compensation point modeling, Biogeosciences, 7 , 537-556, doi:10.5194/bg-7-537-2010, 2010.

Fowler, D., Smith, R. I., Muller, J. B. A., Hayman, G., and Vincent, K. J.: Changes in the atmospheric deposition of acidifying compounds in the UK between 1986 and 2001, Environ. Pollut., 137, 15-25, 2005.

Fowler, D., Cape, N., Smith, R., Nemitz, E., Sutton, M., Dore, T., Coyle, M., Crossley, A., Storeton-West, R., Muller, J., Phillips, G., Thomas, R., Vieno, M., Tang, S., Famulari, D., Twigg, M., Bealey, B., Benham, D., Hayman, G., Lawrence, H., Vincent, K., Fagerli, H., and Simpson, D.: Acid deposition processes final report to Defra, NERC/Centre for Ecology \& Hydrology, 110, 2007.

Fowler, D., Pilegaard, K., Sutton, M., Ambus, P., Raivonen, M., Duyzer, J., Simpson, D., Fagerli, H., Fuzzi, S., Schjoerring, J., Granier, C., Neftel, A., Isaksen, I., Laj, P., Maione, M., Monks, P., Burkhardt, J., Daemmgen, U., Neirynck, J., Personne, E., Wichink-Kruit, R., Butterbach-Bahl, K., Flechard, C., Tuovinen, J., Coyle, M., Gerosa, G., Loubet, B., Altimir, N., Gruenhage, L., Ammann, C., Cieslik, S., Paoletti, E., Mikkelsen, T., Ro-Poulsen,
H., Cellier, P., Cape, J., Horvath, L., Loreto, F., Niinemets, U., Palmer, P., Rinne, J., Misztal, P., Nemitz, E., Nilsson, D., Pryor, S., Gallagher, M., Vesala, T., Skiba, U., Bruggemann, N., Zechmeister-Boltenstern, S., Williams, J., O’Dowd, C., Facchini, M., de Leeuw, G., Flossman, A., Chaumerliac, N., and Erisman, J.: Atmospheric composition change: Ecosystems-Atmosphere interactions, Atmos. Environ., 43, 5193-5267, 2009.

Francis, D. D., Schepers, S. J., and Sims, A. L.: Ammonia exchange from corn foliage during reproductive growth, Agroclimatology Journal, 89, 941-946, 1997.

Galloway, J. N., Aber, J. D., Erisman, J. W., Seitzinger, S. P., Howarth, R. W., Cowling, E. B., and Cosby, B. J.: The Nitrogen Cascade, BioScience, 53, 341-356, 2003.

Garland, J. A.: The dry deposition of sulphur dioxide to land and water surfaces, Proc. R. Soc. Lon Ser.-A, 354, 245-268, 1977.

Génermont, S. and Cellier, P.: A mechanistic model for estimating ammonia volatilization from slurry applied to bare soil, Agr. Forest Meteorol., 88, 145-167, 1997.

Gessler, A., Rienks, M., and Rennenberg, $\mathrm{H} .: \mathrm{NH}_{3}$ and $\mathrm{NO}_{2}$ fluxes between beech trees and the atmosphere - correlation with climatic and physiological parameters, New Phytol., 147, 539-560, 2000.

Hanstein, S., Mattsson, M., Jaeger, H.-J., and Schjoerring, J. K.: Uptake and utilization of atmospheric ammonia in three native Poaceae species: leaf conductances, composition of apoplastic solution and interactions with root nitrogen supply, New Phytol., 141, 71-83, 1999.

Harper, L. A. and Sharpe, R. R.: Nitrogen dynamics in irrigated corn - Soil-Plant nitrogen and atmospheric ammonia transport, Agron. J., 87, 669-675, 1995.

Harrison, R. and Webb, J.: A review of the effect of $\mathrm{N}$ fertilizer type on gaseous emissions, Adv. Agron., 73, 65-108, 2001.

Hartmann, A.: Erarbeitung von Methoden zur Extraktion der Extrazellulärflüssigkeit von Fichtennadeln für die Bestimmung des Ammoniak-Kompensationspunktes, Interdisziplinäres Ökologisches Zentrum, Bergakademie Freiberg, 2005.

Herrmann, B., Mattsson, M., Fuhrer, J., and Schjoerring, J. K.: Leaf-atmosphere $\mathrm{NH}_{3}$ exchange of white clover (Trifolium repens L.) in relation to mineral $\mathrm{N}$ nutrition and symbiotic $\mathrm{N}_{2}$ fixation, J. Exp. Bot., 53, 139-146, 2002.

Herrmann, B., Mattsson, M., Jones, S. K., Cellier, P., Milford, C., Sutton, M. A., Schjoerring, J. K., and Neftel, A.: Vertical structure and diurnal variability of ammonia exchange potential within an intensively managed grass canopy, Biogeosciences, 6 , 15-23, doi:10.5194/bg-6-15-2009, 2009.

Hesterberg, R., Blatter, A., Fahrni, M., Rosset, M., Neftel, A., Eugster, W., and Wanner, H.: Deposition of nitrogen-containing compounds to an extensively managed grassland in central Switzerland, Environ. Pollut., 91, 21-34, 1996.

Hill, P. W., Raven, J. A., Loubet, B., Fowler, D., and Sutton, M. A.: Comparison of gas exchange and bioassay determinations of the ammonia compensation point in Luzula sylvatica (Huds.) Gaud, Plant Physiol., 125, 476-487, 2001.

Hill, P. W., Raven, J. A., and Sutton, M. A.: Leaf age-related differences in apoplastic $\mathrm{NH}_{4}^{+}$concentration, $\mathrm{pH}$ and the $\mathrm{NH}_{3}$ compensation point for a wild perennial, J. Exp. Bot., 53, 277-286, 2002.

Högström, U.: Review of some basic characteristics of the atmospheric surface layer, Bound-Lay. Meteorol., 78, 215-246, 1996. 
Horvath, L., Asztalos, M., Fuhrer, E., Meszaros, R., and Weidinger, T.: Measurement of ammonia exchange over grassland in the Hungarian Great Plain, Agr. Forest Meteorol., 130, 282-298, 2005.

Husted, S. and Schjoerring, J. K.: A computer-controlled system for studying ammonia exchange, photosynthesis and transpiration of plant canopies growing under controlled environmental conditions, Plant Cell Environ., 18, 1070-1077, 1995a.

Husted, S. and Schjoerring, J. K.: Apoplastic pH and Ammonium Concentration in Leaves of Brassica napus L., Plant Physiol., 109, 1453-1460, 1995b.

Husted, S., Mattsson, M., and Schjoerring, J. K.: Ammonia compensation points in two cultivars of Hordeum vulgare L. during vegetative and generative growth, Plant Cell Environ., 19, 12991306, 1996.

Husted, S. and Schjoerring, J. K.: Ammonia flux between oilseed rape plants and the atmosphere in response to changes in leaf temperature, light intensity, and air humidity. Interactions with leaf conductance and apoplastic $\mathrm{NH}_{4}^{+}$and $\mathrm{H}^{+}$concentrations, Plant Physiol., 112, 57-74, 1996.

Husted, S., Hebbern, C. A., Mattsson, M., and Schjoerring, J. K.: A critical experimental evaluation of methods for determination of $\mathrm{NH}_{4}^{+}$in plant tissue, xylem sap and apoplastic fluid, Physiol. Plantarum, 109, 167-179, 2000a.

Husted, S., Schjoerring, J. K., Nielsen, K. H., Nemitz, E., and Sutton, M. A.: Stomatal compensation points for ammonia in oilseed rape plants under field conditions, Agr. Forest Meteorol., 105, 371-383, 2000b.

Jarvis, P. G.: The interpretation of the variations in leaf water potential and stomatal conductance found in canopies in the field, Philos. T. Roy. Soc. B, 273, 293-310, 1976.

Jensen, N. O. and Hummelshøj, P.: Derivation of canopy resistance for water vapour fluxes over a spruce forest, using a new technique for the viscous sub-layer resistance, Agr. Forest Meteorol., 73, 339-352, 1995.

Jensen, N. O. and Hummelshøj, P.: Erratum, Agr. Forest Meteorol., 85, 289-289, 1997.

Jones, M. R., Leith, I. D., Fowler, D., Raven, J. A., Sutton, M. A., Nemitz, E., Cape, J. N., Sheppard, L. J., Smith, R. I., and Theobald, M. R.: Concentration-dependent $\mathrm{NH}_{3}$ deposition processes for mixed moorland semi-natural vegetation, Atmos. Environ., 41, 2049-2060, 2007a.

Jones, M. R., Leith, I. D., Raven, J. A., Fowler, D., Sutton, M. A., Nemitz, E., Cape, J. N., Sheppard, L. J., and Smith, R. I.: Concentration-dependent $\mathrm{NH}_{3}$ deposition processes for moorland plant species with and without stomata, Atmos. Environ., 41, 8980-8994, 2007b.

Kesselmeier, J., Merk, L., Bliefernicht, M., and Helas, G.: Trace gas exchange between terrestrial plants and atmosphere: carbon dioxide, carbonyl sulfide and ammonia under the rule of compensation points, in: General Assessment of Biogenic emissions and Deposition of Nitrogen Compounds, sulphur compounds and oxidants in Europe, Brussels, 71-80, 1993.

Klemm, O., Milford, C., Sutton, M. A., Spindler, G., and van Putten, E.: A climatology of leaf surface wetness, Theor. Appl. Climatol., 71, 107-117, 2002.

Krupa, S. V.: Effects of atmospheric ammonia $\left(\mathrm{NH}_{3}\right)$ on terrestrial vegetation: a review. Environ. Pollut., 124, 179-221, 2003.

Lafleur, P. M. and Rouse, W. R.: Application of an energy combi- nation model for evaporation from sparse canopies, Agr. Forest Meteorol., 49, 135-153, 1990.

Lambers, H., Chapin III, F. S., and Pons, T. L.: Plant physiological ecology, 2nd ed., edited by: Springer-Verlag, New York, 610 pp., 2008.

Langford, A. O. and Fehsenfeld, F. C.: Natural vegetation as a source or sink for atmospheric ammonia - a case-study, Science, 255, 581-583, 1992.

Lemon, E. and Van Houtte, R.: Ammonia Exchange at the Land Surface, Agron. J., 72, 876-883, 1980.

Loubet, B., Milford, C., Hill, P. W., Sim Tang, Y., Cellier, P., and Sutton, M. A.: Seasonal variability of apoplastic $\mathrm{NH}_{4}^{+}$and $\mathrm{pH}$ in an intensively managed grassland, Plant Soil, 238, 97-110, 2002.

Manderscheid, R., Schaaf, S., Mattsson, M., and Schjoerring, J. K. Glufosinate treatment of weeds results in ammonia emission by plants, Agr. Ecosyst. Environ., 109, 129-140, 2005.

Massad, R.-S., Loubet, B., Tuzet, A., Autret, H., and Cellier, P.: Ammonia stomatal compensation point of young oilseed rape leaves during dark/light cycles under various nitrogen nutritions, Agr. Ecosyst. Environ., 133, 170-182, 2009.

Massad, R.-S., Tuzet, A., Loubet, B., Perrier, A., and Cellier, P.: Model of stomatal ammonia compensation point (STAMP) in relation to the plant nitrogen and carbon metabolisms and environmental conditions, Ecol. Model., 221, 479-494, 2010.

Massad, R. S., Loubet, B., Tuzet, A., and Cellier, P.: Relationship between ammonia stomatal compensation point and nitrogen metabolism in arable crops: Current status of knowledge and potential modelling approaches, Environ. Pollut., 154, 390-403, 2008.

Massman, W. J.: A review of the molecular diffusivities of $\mathrm{H}_{2} \mathrm{O}$, $\mathrm{CO}_{2}, \mathrm{CH}_{4}, \mathrm{CO}, \mathrm{O}_{3}, \mathrm{SO}_{2}, \mathrm{NH}_{3}, \mathrm{~N}_{2} \mathrm{O}, \mathrm{NO}$, and $\mathrm{NO}_{2}$ in air, $\mathrm{O}_{2}$ and $\mathrm{N}_{2}$ near STP, Atmos. Environ., 32, 1111-1127, 1998.

Mattsson, M. and Schjoerring, J. K.: Ammonia emission from young barley plants: Influence of $\mathrm{N}$ source, light/dark cycles and inhibition of glutamine synthetase, J. Exp. Bot., 47, 477-484, 1996.

Mattsson, M., Hausler, R. E., Leegood, R. C., Lea, P. J., and Schjoerring, J. K.: Leaf-atmosphere $\mathrm{NH}_{3}$ exchange in barley mutants with reduced activities of glutamine synthetase, Plant Physiol., 114, 1307-1312, 1997.

Mattsson, M., Husted, S., and Schjoerring, J. K.: Influence of nitrogen nutrition and metabolism on ammonia volatilization in plants, Nutr. Cycl. Agroecosys., 51, 35-40, 1998.

Mattsson, M. and Schjoerring, J. K.: Dynamic and steady-state responses of inorganic nitrogen pools and $\mathrm{NH}_{3}$ exchange in leaves of Lolium perenne and Bromus erectus to changes in root nitrogen supply, Plant Physiol., 128, 742-750, 2002.

Mattsson, M. and Schjoerring, J. K.: Senescence-induced changes in apoplastic and bulk tissue ammonia concentrations of ryegrass leaves, New Phytol., 160, 489-499, 2003.

Mattsson, M., Herrmann, B., David, M., Loubet, B., Riedo, M., Theobald, M. R., Sutton, M. A., Bruhn, D., Neftel, A., and Schjoerring, J. K.: Temporal variability in bioassays of the stomatal ammonia compensation point in relation to plant and soil nitrogen parameters in intensively managed grassland, Biogeosciences, 6, 171-179, doi:10.5194/bg-6-171-2009, 2009a.

Mattsson, M., Herrmann, B., Jones, S., Neftel, A., Sutton, M. A., and Schjoerring, J. K.: Contribution of different grass species to plant-atmosphere ammonia exchange in intensively managed 
grassland, Biogeosciences, 6, 59-66, doi:10.5194/bg-6-59-2009, 2009 b.

McCalley, C. and Sparks, J.: Controls over nitric oxide and ammonia emissions from Mojave Desert soils, Oecologia, 156, 871$881,2008$.

Milford, C., Hargreaves, K. J., Sutton, M. A., Loubet, B., and Cellier, P.: Fluxes of $\mathrm{NH}_{3}$ and $\mathrm{CO}_{2}$ over upland moorland in the vicinity of agricultural land, J. Geophys. Res-Atmos., 106, 24169-24181, 2001a.

Milford, C., Theobald, M. R., Nemitz, E., and Sutton, M. A.: Dynamics of ammonia exchange in response to cutting and fertilising in an intensively-managed grassland, Water Air Soil Pollut: Focus, 1, 167-176, 2001b.

Milford, C.: Dynamics of atmospheric ammonia exchange with intensively-managed grassland, $\mathrm{PhD}$ Thesis, University of Edinburgh, 230 pp., 2004.

Milford, C., Theobald, M. R., Nemitz, E., Hargreaves, K. J., Horvath, L., Raso, J., Dämmgen, U., Neftel, A., Jones, S. K., Hensen, A., Loubet, B., Cellier, P., and Sutton, M. A.: Ammonia fluxes in relation to cutting and fertilization of an intensively managed grassland derived from an inter-comparison of gradient measurements, Biogeosciences, 6, 819-834, doi:10.5194/bg-6819-2009, 2009.

Monin, A. S. and Obukhov, A. M.: Basic laws of turbulent mixing in the atmosphere near the ground, Tr. Geofiz. Inst., Akad. Nauk SSSR, 24, 163-187, 1954.

Monteith, J. L.: Principles of Environmental Physics, edited by: Arnold, E., London, 1973.

Monteith, J. L. and Unsworth, M. H.: Principles of Environmental Physics. 2nd Edition, Arnold Press, London, 291 pp., 1990.

Morgan, J. A. and Parton, W. J.: Characteristics of ammonia volatilization from spring wheat, Crop Sci., 29, 726-731, 1989.

Mosier, A. R., Kroeze, C., Nevison, C., Oenema, O., and Seitzinger, S.: Closing the global atmospheric $\mathrm{N}_{2} \mathrm{O}$ budget: nitrous oxide emissions through the agricultural nitrogen cycle, Nutr. Cycl. Agroecosys., 52, 225-248, 1998.

Neirynck, J., Kowalski, A. S., Carrara, A., Genouw, G., Berghmans, P., and Ceulemans, R.: Fluxes of oxidised and reduced nitrogen above a mixed coniferous forest exposed to various nitrogen emission sources, Environ. Pollut., 149, 31-43, 2007.

Neirynck, J. and Ceulemans, R.: Bidirectional ammonia exchange above a mixed coniferous forest, Environ. Pollut., 154, 424-438, 2008.

Nemitz, E., Sutton, M. A., Gut, A., San Jose, R., Husted, S., and Schjoerring, J. K.: Sources and sinks of ammonia within an oilseed rape canopy, Agr. Forest Meteorol., 105, 385-404, 2000a.

Nemitz, E., Sutton, M. A., Schjoerring, J. K., Husted, S., and Wyers, G. P.: Resistance modelling of ammonia exchange over oilseed rape, Agr. Forest Meteorol., 105, 405-425, 2000b.

Nemitz, E., Milford, C., and Sutton, M. A.: A two-layer canopy compensation point model for describing bi-directional biosphere-atmosphere exchange of ammonia, Q. J. Roy Meteor. Soc., 127, 815-833, 2001.

Nemitz, E., Sutton, M. A., Wyers, G. P., and Jongejan, P. A. C.: Gas-particle interactions above a Dutch heathland: I. Surface exchange fluxes of $\mathrm{NH}_{3}, \mathrm{SO}_{2}, \mathrm{HNO}_{3}$ and $\mathrm{HCl}$, Atmos. Chem. Phys., 4, 989-1005, doi:10.5194/acp-4-989-2004, 2004.

Nielsen, K. H. and Schjoerring, J. K.: Regulation of apoplastic
$\mathrm{NH}_{4}^{+}$concentration in leaves of oilseed rape, Plant Physiol., 118, 1361-1368, 1998

Personne, E., Loubet, B., Herrmann, B., Mattsson, M., Schjoerring, J. K., Nemitz, E., Sutton, M. A., and Cellier, P.: SURFATMNH3: a model combining the surface energy balance and bidirectional exchanges of ammonia applied at the field scale, Biogeosciences, 6, 1371-1388, doi:10.5194/bg-6-1371-2009, 2009.

Pitcairn, C. E. R., Leith, I. D., L.J., S., van Dijk, N., Tang, Y. S., Wolseley, P. A., James, P. W., and Sutton, M. A.: Bioindicator methods for assessing effects of atmospheric nitrogen on statutory nature conservation sites. Appendix I. Field intercomparison of different bio-indicator methods, JNCC Report 386, Peterborough, UK, 141-181, 2004

Plantaz, M. A. H. G., Slanina, J., and Wyers, G. P.: Surface/atmosphere exchange of ammonia over grazed pasture. Energieonderzoek Centrum Nederland, Petten, The Netherlands, 1996.

Provolo, G. and Martínez-Suller, L.: In situ determination of slurry nutrient content by electrical conductivity, Bioresource Technol., 98, 3235-3242, 2007.

Ramanathan, V., Ramana, M. V., Roberts, G., Kim, D., Corrigan, C., Chung, C., and Winker, D.: Warming trends in Asia amplified by brown cloud solar absorption, Nature, 448, 575-578, 2007.

Rattray, G. and Sievering, H.: Dry deposition of ammonia, nitric acid, ammonium, and nitrate to alpine tundra at Niwot Ridge, Colorado, Atmos. Environ., 35, 1105-1109, 2001.

Raupach, M. R.: Applying Lagrangian fluid mechanics to infer scalar source distributions from concentration profiles in plant canopies, Agr. Forest Meteorol., 47, 85-108, 1989.

Riedo, M., Milford, C., Schmid, M., and Sutton, M. A.: Coupling soil-plant-atmosphere exchange of ammonia with ecosystem functioning in grasslands, Ecol. Model., 158, 83-110, 2002.

Rudich, Y., Benjamin, I., Naaman, R., Thomas, E., Trakhtenberg, S., and Ussyshkin, R.: Wetting of hydrophobic organic surfaces and its implications to organic aerosols in the atmosphere, $\mathrm{J}$. Phys. Chem. A, 104, 5238-5245, 2000.

Sarwar, G., Corsi, R. L., Kinney, K. A., Banks, J. A., Torres, V. M., and Schmidt, C.: Measurements of ammonia emissions from oak and pine forests and development of a non-industrial ammonia emissions inventory in Texas, Atmos. Environ., 39, 7137-7153, 2005.

Schjoerring, J. K., Kyllingsbaek, A., Mortensen, J. V., and ByskovNielsen, S.: Field investigations of ammonia exchange between barley plants and the atmosphere. I. Concentration profiles and flux densities of ammonia, Plant Cell Environ., 16, 161-167, 1993.

Schjoerring, J. K., Husted, S., and Mattsson, M.: Physiological parameters controlling plant-atmosphere ammonia exchange, Atmos. Environ., 32, 491-498, 1998a.

Schjoerring, J. K., Husted, S., and Poulsen, M. M.: Soil-plantatmosphere ammonia exchange associated with Calluna vulgaris and Deschampsia flexuosa, Atmos. Environ., 32, 507-512, 1998b.

Schjoerring, J. K., Husted, S., Mack, G., and Mattsson, M.: The regulation of ammonium translocation in plants, J. Exp. Botany, 53, 883-890, 2002.

Schuepp, P. H.: Turbulent transfer at the ground: On verification of a simple predictive model, Bound-Lay. Meteorol., 12, 171-186, 
1977.

Shuttleworth, W. J. and Wallace, J. S.: Evaporation from sparse crops - an energy combination theory, Q. J. Roy Meteor. Soc., $111,839-855,1985$.

Simpson, D., Fagerli, H., Jonson, J. E., Tsyro, S., Wind, P., and Tuovinen, J. P.: Transboundary acidification and eutrophication and ground level ozone in Europe: Unified EMEP Model Description. EMEP Status Report 1/2003 Part I, The Norwegian Meteorological Institute, Oslo, Norway, 2003.

Simpson, D., Butterbach-Bahl, K., Fagerli, H., Kesik, M., Skiba, U., and Tang, S.: Deposition and emissions of reactive nitrogen over European forests: A modelling study, Atmos. Environ., 40, 5712-5726, 2006.

Sommer, S. G. and Jensen, E. S.: Foliar absorption of atmospheric ammonia by ryegrass in the field, J. Environ. Qual., 20, 153-156, 1991.

Sorteberg, A. and Hov, Ø.: Two parametrizations of the dry deposition exchange for $\mathrm{SO}_{2}$ and $\mathrm{NH}_{3}$ in a numerical model, Atmos. Environ., 30, 1823-1840, 1996.

Spindler, G., Teichmann, U., and Sutton, M. A.: Ammonia dry deposition over grassland - micrometeorological flux-gradient measurements and bidirectional flux calculations using an inferential model, Q. J. Roy Meteor. Soc., 127, 795-814, 2001.

Sutton, M. A., Moncrieff, J. B., and Fowler, D.: Deposition of atmospheric ammonia to moorlands, Environ.Pollut., 75, 15-24, 1992.

Sutton, M. A. and Fowler, D.: A model for inferring bi-directional fluxes of ammonia over plant canopies, in: WMO Conference on the Measurement and Modeling of Atmospheric Composition Changes including Pollution Transport, WMO/GAW, WMO, Geneva, CH, Sofia, Bulgaria, October, 179-182, 1993.

Sutton, M. A., Fowler, D., Moncrieff, J. B., and Storeton-West, R. L.: The exchange of atmospheric ammonia with vegetated surfaces I. Unfertilized vegetation, Q. J. Roy Meteor. Soc., 119, 1023-1045, 1993a.

Sutton, M. A., Fowler, D., Moncrieff, J. B., and Storeton-West, R. L.: The exchange of atmospheric ammonia with vegetated surfaces II. Fertilized vegetation, Q. J. Roy Meteor. Soc., 119, 10471070, 1993b.

Sutton, M. A., Pitcairn, C. E. R., and Fowler, D.: The exchange of ammonia between the atmosphere and plant communities, Adv. Ecol. Res., 24, 301-393, 1993c.

Sutton, M. A., Asman, W. A. H., and Schjoerring, J. K.: Dry deposition of reduced nitrogen, Tellus B, 46B, 255-273, 1994.

Sutton, M. A., Burkhardt, J. K., Guerin, D., and Fowler, D.: Measurement and modelling of ammonia exchange over arable croplands, in: Acid Rain Research: Do We Have Enough Answers?, edited by: Heij, G. J. and Erisman, J. W., Elsevier, Amsterdam, 64, 71-80, 1995a.

Sutton, M. A., Schjoerring, J. K., and Wyers, G. P.: Plantatmosphere exchange of ammonia, Philos. T. Roy. Soc. S-A, 351, 261-278, 1995b.

Sutton, M. A., Hill, P. W., Fowler, D., and Raven, J. A.: Impacts of nitrogen deposition on plant physiological parameters controlling the ammonia compensation point, Annual report of ITE to the Department of the Environment, 1996a.

Sutton, M. A., Nemitz, E., Fowler, D., Wyers, G. P., Otjes, R. P., San José, R., Moreno, J., Schjørring, J. K., Husted, S., Meixner, F. X., Ammann, C., Neftel, A., and Gut, A.: Exchange of atmo- spheric ammonia with European ecosystems (EXAMINE), Final Report to the European Commission, Institute of Terrestrial Ecology, Edinburgh, 266, 1996 b.

Sutton, M. A., Milford, C., Dragosits, U., Singles, R., Fowler, D., Ross, C., Hill, R., Jarvis, S. C., Pain, B. F., Harrison, D., Moss, D., Webb, J., Espenhahn, S., Halliwell, C., Lee, D. S., Wyers, G. P., Hill, J., and ApSimon, H. M.: Gradients of atmospheric ammonia concentrations and deposition downwind of ammonia emissions: first results of the ADEPT Burrington Moor Experiment, in: Gaseous Exchange with Grassland Systems, edited by: Jarvis, S. C. and Pain, B. P., CAB International Wallingford, 131-139, 1997.

Sutton, M. A., Burkhardt, J. K., Guerin, D., Nemitz, E., and Fowler, D.: Development of resistance models to describe measurements of bi-directional ammonia surface-atmosphere exchange, Atmos. Environ., 32, 473-480, 1998a.

Sutton, M. A., Milford, C., Dragosits, U., Place, C. J., Singles, R. J., Smith, R. I., Pitcairn, C. E. R., Fowler, D., Hill, J., ApSimon, H. M., Ross, C., Hill, R., Jarvis, S. C., Pain, B. F., Phillips, V. C., Harrison, R., Moss, D., Webb, J., Espenhahn, S. E., Lee, D. S., Hornung, M., Ullyett, J., Bull, K. R., Emmett, B. A., Lowe, J., and Wyers, G. P.: Dispersion, deposition and impacts of atmospheric ammonia: quantifying local budgets and spatial variability, Environ. Pollut., 102, 349-361, 1998b.

Sutton, M. A., Nemitz, E., Fowler, D., Wyers, G. P., Otjes, R. P., Schjoerring, J. K., Husted, S., Nielsen, K. H., San José, R., Moreno, J., Gallagher, M. W., and Gut, A.: Fluxes of ammonia over oilseed rape: Overview of the EXAMINE experiment, Agr. Forest Meteorol., 105, 327-349, 2000.

Sutton, M. A., Milford, C., Nemitz, E., Theobald, M. R., Hargreaves, K. J., Fowler, D., Schjoerring, J. K., Mattsson, M. E., Husted, S., Erisman, J. W., Hensen, A., Mosquera, J., Otjes, R., Jonejon, P., Cellier, P., Loubet, B., David, M., Neftel, A., Blatter, A., Hermann, B., Jones, S. K., Horvath, L., Weidinger, T., Raso, J., Meszaros, R., Fuhrer, E., Mantzanas, C., Koukoura, Z., Papanastasis, V., Gallagher, Z. M., Dorsey, J. R., Flynn, M., and Riedo, M.: Biosphere-atmosphere interactions of ammonia with European Grasslands. Final Synthesis Report 1, European Comission, Center for Ecology and Hydrology, Edinburgh, 69 pp., 2002.

Sutton, M. A., Asman, W. A. H., Ellermann, T., Van Jaarsveld, J. A., Acker, K., Aneja, V., Duyzer, J., Horvath, L., Paramonov, S., Mitosinkova, M., Tang, Y. S., Achermann, B., Gauger, T., Bartniki, J., Neftel, A., and Erisman, J. W.: Establishing the link between ammonia emission control and measurements of reduced nitrogen concentrations and deposition, Environ. Monit. Assess., 82, 149-185, 2003.

Sutton, M. A., Erisman, J. W., Dentener, F., and Möller, D.: Ammonia in the environment: From ancient times to the present, Environ.Pollut., 156, 583-604, 2008.

Sutton, M. A., Nemitz, E., Milford, C., Campbell, C., Erisman, J. W., Hensen, A., Cellier, P., David, M., Loubet, B., Personne, E., Schjoerring, J. K., Mattsson, M., Dorsey, J. R., Gallagher, M. W., Horvath, L., Weidinger, T., Meszaros, R., Dämmgen, U., Neftel, A., Herrmann, B., Lehman, B. E., Flechard, C., and Burkhardt, J.: Dynamics of ammonia exchange with cut grassland: synthesis of results and conclusions of the GRAMINAE Integrated Experiment, Biogeosciences, 6, 2907-2934, doi:10.5194/bg-6-29072009, 2009a. 
Sutton, M. A., Nemitz, E., Theobald, M. R., Milford, C., Dorsey, J. R., Gallagher, M. W., Hensen, A., Jongejan, P. A. C., Erisman, J. W., Mattsson, M., Schjoerring, J. K., Cellier, P., Loubet, B., Roche, R., Neftel, A., Hermann, B., Jones, S. K., Lehman, B. E., Horvath, L., Weidinger, T., Rajkai, K., Burkhardt, J., Löpmeier, F. J., and Daemmgen, U.: Dynamics of ammonia exchange with cut grassland: strategy and implementation of the GRAMINAE Integrated Experiment, Biogeosciences, 6, 309331, doi:10.5194/bg-6-309-2009, 2009b.

Sutton, M. A., Reis, S., and Baker, S. (Eds.): Atmospheric ammonia: detecting emission changes and environmental impacts. Results of an expert workshop under the convention on long-range transboundary air pollution, Springer, 2009c.

Trebs, I., Meixner, F. X., Slanina, J., Otjes, R., Jongejan, P., and Andreae, M. O.: Real-time measurements of ammonia, acidic trace gases and water-soluble inorganic aerosol species at a rural site in the Amazon Basin, Atmos. Chem. Phys., 4, 967-987, doi:10.5194/acp-4-967-2004, 2004.

van Hove, L. W. A., Koops, A. J., Adema, E. H., Vredenberg, W. J., and Pieters, G. A.: Analysis of the uptake of atmospheric ammonia by leaves of Phaseolus vulgaris L., Atmos. Environ., 21, 1759-1763, 1987.

van Hove, L. W. A., Adema, E. H., Vredenberg, W. J., and Pieters, G. A.: A study of the adsorption of $\mathrm{NH}_{3}$ and $\mathrm{SO}_{2}$ on leaf surfaces, Atmos. Environ., 23, 1479-1486, 1989.

van Hove, L. W. A. and Adema, E. H.: The effective thickness of water films on leaves, Atmos. Environ., 30, 2933-2936, 1996.

van Hove, L. W. A., Heeres, P., and Bossen, M. E.: The annual variation in stomatal ammonia compensation point of rye grass (Lolium perenne L.) leaves in an intensively managed grassland, Atmos. Environ., 36, 2965-2977, 2002.

van Pul, A., Hertel, O., Geels, C., Dore, A., Vieno, M., van Jaarsveld, H. A., Bergstrom, R., Schaap, M., and Fagerli, H.: Modelling of the atmospheric transport and deposition of ammonia at a national and regional scale, in: Atmospheric Ammonia Detecting emission changes and environmental impacts. Results of an expert workshop under the convention of long-range transboundary air pollution, edited by: Sutton, M. A., Reis, S., Baker, S. M. H., Springer, 301-358, 2009.

Vautard, R., Beekmann, M., Roux, J., and Gombert D. : Validation of a hybrid forecasting system for the ozone concentrations over the Paris area, Atmos. Environ., 35, 2449-2461, 2001.

Vieno, M.: The use of an atmospheric chemistry - transport model (FRAME) over the UK and development of its numerical and physical schemes, PhD Thesis, University of Edinburgh, 2006.

Walker, J. T., Robarge, W. P., Wu, Y., and Meyers, T. P.: Mea- surement of bi-directional ammonia fluxes over soybean using the modified Bowen-ratio technique, Agr. Forest Meteorol., 138, 54-68, 2006.

Walker, J., Spence, P., Kimbrough, S., and Robarge, W. P.: Inferential model estimates of ammonia dry deposition in the vicinity of a swine production facility, Atmos. Environ., 42, 3407-3418, 2008.

Wang, Y. P. and Leuning, R.: A two-leaf model for canopy conductance, photosynthesis and partitioning of available energy I: Model description and comparison with a multi-layered model, Agr. Forest Meteorol., 91, 89-111, 1998.

Wesely, M. L.: Parameterization of surface resistances to gaseous dry deposition in regional scale numerical models, Atmos. Environ., 23, 1293-1304, 1989.

Wichink-Kruit, R. J., Jacobs, A. F. G., and Holtslag, A. A. M.: Measurements and estimates of leaf wetness over agricultural grassland for dry deposition modeling of trace gases, Atmos. Environ., 42, 5304-5316, 2008.

Wichink-Kruit, R. J., van Pul, W. A. J., Otjes, R. P., Hofschreuder, P., Jacobs, A. F. G., and Holtslag, A. A. M.: Ammonia fluxes and derived canopy compensation points over non-fertilized agricultural grassland in The Netherlands using the new gradient ammonia-high accuracy-monitor (GRAHAM), Atmos. Environ., 41, 1275-1287, 2007.

Wichink-Kruit, R. J., van Pul, W. A. J., Sauter, F. J., van den Broek, M., Nemitz, E., Sutton, M. A., Krol, M., and Holtslag, A. A. M.: Modeling the surface-atmosphere exchange of ammonia, Atmos. Environ., 44, 945-957, 2010.

Wu, Y. H., Walker, J., Schwede, D., Peters-Lidard, C., Dennis, R., and Robarge, W.: A new model of bi-directional ammonia exchange between the atmosphere and biosphere: Ammonia stomatal compensation point, Agr. Forest Meteorol., 149, 263-280, 2009.

Wyers, G. P. and Erisman, J. W.: Ammonia exchange over coniferous forest, Atmos. Environ., 32, 441-451, 1998.

Yamulki, S., Harrison, R. M., and Goulding, K. W. T.: Ammonia surface-exchange above an agricultural field in southeast England, Atmos. Environ., 30, 109-118, 1996.

Zhang, L., Brook, J. R., and Vet, R.: A revised parameterization for gaseous dry deposition in air-quality models, Atmos. Chem. Phys., 3, 2067-2082, doi:10.5194/acp-3-2067-2003, 2003.

Zhang, L., Wright, P. L., and Asman, W. A. H.: Bi-directional airsurface exchange of atmospheric ammonia - A review of measurements and a development of a big-leaf model for applications in regional-scale air-quality models, J. Geophys. Res., 115, D20310, doi:10.1029/2009JD013589, 2010. 